\title{
Notes on the history and the syntax of Mauritian Creole ${ }^{1}$
}

\author{
PIETER A. M. SEUREN
}

Abstract

The central question behind the various topics discussed in this paper is the question of the LINGUISTIC status of Creole languages. They do have similar historical backgrounds, but do they also have linguistic features in common, and if so, how can they be explained? Certain features of the history and syntax of Mauritian Creole (MC) are used to bring more light to this problem area. The view is defended that $M C$ was not, or not significantly, influenced by any West African languages. Verb serialization and predicate clefting, two clearly West African linguistic features found in the Caribbean Creoles, are notably absent in MC. No other convincingly West African features can be identified. The highly particular features common to MC and the French-based Caribbean Creoles are tentatively attributed to a French-based nautical pidgin and/or Creole in French trading posts in East and West Africa. Against this background a few MC-specific grammatical phenomena, in particular the rule of verb apocope, in connection with phenomena of verb complementation, the formation of WH-words, and the system of preverbal markers for tense, modality, and aspect, are described and analyzed. $M C$ appears to have two raising rules, predicate raising and subject raising, which alternate in such a way that SVO word order is not disturbed. It is shown that all the phenomena in question manifest a tendency to maximize semantic transparency (in the sense that the amount of processing required to get from semantic structures to surface structures and vice versa is minimized). The idea is put forward that semantic transparency is a powerful determinant in the genesis of Creole languages generally. It is argued, furthermore, that no evidence is available for any Creole-specific substantive universals.

\section{Introduction}

Mauritian Creole (MC) is the national language of the Indian Ocean island Mauritius. In 1598 the Dutch took possession of the then uninhab- 
ited island and named it Mauritius, after Prince Maurice of Nassau, then Stadhouder of the Dutch Republic. The Dutch mainly limited themselves to cutting hardwood trees and hunting (thereby making the Dodo extinct). They did little to establish a plantation culture, though they introduced the sugar cane, without knowing, at first, how to make sugar: for some time they only made an alcoholic drink from the cane. In 1710, when the Dutch had lost interest in India they abandoned Mauritius, which had served mainly as a provisioning station on the ship route between the Cape and India. In 1715 the French occupied the island from the neighboring Île Bourbon, now Réunion. Fifteen years later they started a serious settlement, trying out a variety of products, only to concentrate, in the end, on sugar. The French imported slaves from Madagascar and East Africa, and to some extent also from West Africa, though opinions differ on both the exact numbers and their relevance for the origins of $\mathrm{MC}$ (see section 1). MC is a typical case of a Creole language developing in the context of a settlers' economy worked by imported slaves. In 1810 the British conquered the island and kept it until 1968, when it gained independence.

Slavery was abolished in 1835 . In order to provide the steadily growing economy of the island with the necessary labor force the British resorted, on a much larger scale than before, to the importation of indentured laborers. As everywhere else, the main quarry for indentured labor was India, from where laborers poured in under contract. More than half the population of Mauritius today is of Indian descent (with some racial mixing). Apart from the Creoles, who are descended from the original African slaves, and the Indians, there are also many Chinese, about $10 \%$ of the population. These keep very much to themselves and are mainly shopkeepers.

As a result of this history, the linguistic situation is rather complex. Apart from the two official languages, French and English, there is MC, spoken by virtually all Mauritians, and the so-called ancestral languages, the languages imported from India and China (no African language was imported). English is the language of government and of social prestige. French is the linguistic model for upper- and middle-class speakers (though there does not seem to be a continuum from basilectal Creole to acrolectal French [Stein 1984: 109]). MC is the normal medium of oral communication everywhere, but it is seldom written and is not taught at all in the schools. (In fact, there is a great deal of popular resistance to the idea that MC should be used or taught in the schools, as parents feel that their children need one or more world languages, not the humble vernacular, to be successful in life.) The ancestral languages are dying out, despite government efforts to preserve them. Their active use is 
limited to isolated pockets in Mauritian society, consisting mainly of elderly and/or rural families. Passive competence, however, is still fairly widespread among the Indians, due to family traditions, to tv programs, and to the fact that these languages are optionally taught from the age of six. MC is thus clearly disadvantaged scholastically, even if it is, in practice, the national language of the island. ${ }^{2}$

\section{Some historical aspects}

MC is a French-based Creole language, in the current sense of that term. What that term implies from a purely linguistic point of view is still far from clear. The class of Creole languages is delimited mainly on historical grounds. But whether there are also linguistic features characteristic of just these languages is still very much a moot point, and so is the question of the causal factors behind any possible Creole linguistic universals. The linguistic study of Creole languages is relatively young (it started about a hundred years ago), and the practitioners have been scarce. Their inevitable handicap has always been the lack of sufficient expert knowledge of the languages involved, and of the historical details necessary to decide between competing theories of diachronic development. In spite of this handicap, the history of Creole linguistics is studded with general theories about the genesis of Creole languages and their linguistic characteristics. Whereas most of these theories have been presented with the caution required by the circumstances, some are more clamorous. In particular, Bickerton $(1981,1984)$ makes far-reaching claims about how Creole languages arise. Their origin is linked with an alleged biological fixation, in an undefined sense, of what are claimed to be universal Creole linguistic features in the human brain. This linguistic "bioprogram" is identified with Chomsky's "core grammar" (Chomsky 1981). This "core grammar" overgenerates so grossly that virtually any claim can be rested on it. Yet it fails to generate the verb apocope phenomena discussed in section 4, and it fails entirely to account for the phenomena of verb complementation discussed in section 5 . Given our still highly incomplete knowledge of both linguistic and historical details of crucial importance, together with the uncertain and defective state of linguistic theory, especially as regards psychologically relevant semantics, and the vacuousness of claims about biological reality, it would seem that less ambitious and more cautious theories are more useful to enhance our insight into these matters.

Specific and detailed grammatical analyses and descriptions of MC are relatively scarce. There is the delightful book by Charles Baissac, pub- 
lished in 1880: 230 (small) pages of information on the language and its history, plus texts and proverbs (in a spelling that purposely reflects French origins). In 1888 Baissac also published a substantial collection of $\mathrm{MC}$ folk texts with French translations. His work is especially valuable since very little material is available on earlier stages of MC (see Chaudenson 1981). Contemporary studies include Virahsawmy (1967), Corne (1970), and Baker (1972), along with a number of publications dealing with specific topics in the grammar of MC.

The origins of MC are controversial. Some (in particular Baker and Corne 1982) claim substantial West African influence in MC, which for them is closely related to the Caribbean Creoles. Others (in particular Chaudenson 1979a) hold that MC is largely derived from the Creole spoken in Réunion in the early eighteenth century. Others again (notably Faine 1939; Goodman 1964; Hull 1979) envisage a French nautical patois developed in the seventeenth century along the African west coast as the major input to MC. The main problem to be solved, in this context, is the presence of a number of highly specific features shared by MC (and to some extent the other French-based Indian Ocean Creoles) and Frenchbased Creoles in the Caribbean, in particular Haitian Creole. These features are numerous enough for there to be a high degree of mutual comprehensibility between MC and Haitian. ${ }^{3}$ Some of these features are of such a nature that a historical link must be assumed. Thus, to mention a few outstanding examples, both Haitian Creole and MC have a postposed definite article spanning even the relative clause; ${ }^{4}$ both have the particle fek, from French fait que, meaning 'just now, a moment ago'; both have the preverbal particle ape (in various shapes) for habitual progressive aspect. Ape derives from French après in the original meaning of 'close by' (i.e. the meaning of auprès); the use of après to indicate this verbal aspect was until recently colloquial French (Grevisse 1969). Not one typical feature of French Creoles seems to stem from other (African) languages: they are all French, whether standard or dialectal or sociolectal. The question is, how and in what direction did such features travel? The evidence is puzzling, and it has led many researchers to favor theories that imply linguistic influence from West Africa, one way or another, on MC. The view taken here is, however, that those theories are unwarranted, and that it is more likely that the linguistic features in question travelled from the Indian Ocean to the Caribbean than from west to east, if they travelled at all.

In short, what could explain those similarities between MC and Frenchbased Caribbean Creoles that are not derivable from internal (universal) linguistic factors that are assumed to be at work when pidgins or creoles arise as "languages of convenience"? That is, what historical circum- 
stances may have made it possible for common nonuniversal linguistic features to be found in MC and the Caribbean French-based Creoles? Is West Africa the common link, as is proposed by Baker and Corne (1982)?

The main problem with this otherwise attractive theory is that there is no clear indication of West African linguistic influence in MC. In fact, those elements that are found in all Caribbean Creoles and are CLEARLY of West African origin, such as verb serialization and predicate clefting, are virtually absent in MC. Alleyne (1980: 11-13) lists a number of features shared by the Caribbean Creole languages: (a) preverbal particles marking tenses, modalities, and aspects, (b) verb serialization, (c) topicalization (predicate clefting), (d) nonmorphological passive, (e) genitive construction, (f) pluralization, (g) gender designation, (h) question words, and (i) reflexives. Of these features, (a) is found in $\mathrm{MC}$, but, as is shown in section 7, this may have more to do with semantic transparency than with West African influence, in particular since there is no unambiguous West African source for it. The nonmorphological passive, feature (d), is also found in MC, but MC has a fully developed agent phrase, which the Caribbean Creoles lack. Feature (e), the genitive construction, is common in $\mathrm{MC}$, but also in a large number of languages in the world. Gender designation, that is, the designation of animal gender by noun specifiers like 'man' or 'woman' ('boy', 'girl'), resulting in formations like 'man-pig', is alien to MC. Feature (h), specific question (WH-) words, is indeed typical of MC, which forms WH-words by means of a general question marker $k i$ and a specifier of place, manner, reason, time, etc. In section 6 it will be argued that this is, again, a manifestation of the tendency to maximize semantic transparency and not clearly a West African element. In any case, no African source can be pointed out. On the other hand, those features that clearly do have a West African source, verb serialization and predicate clefting, are never or hardly ever found in MC. The linguistic evidence is thus not at all suggestive of West African influence upon MC.

The anthropological evidence is likewise negative. There is no Voodoo in Mauritius, no spider stories, no day-names, no seven-days burial ritual, etc. Yet all these cultural elements are prominently present in the Caribbean area.

A massive amount of historical data is available on the population and the slave trade in the Mascarene Islands, and many excellent historians have presented the data in extenso. Filliot (1974) is a good digest of the enormous amount of work done by the earlier historians on slave imports in these islands. Filliot informs us (1974: 116) that in the period immediately following the year 1650 the English bought many East African slaves and sold them to Barbadian and Jamaican planters. In 
the later period up to 1720 it was the widely feared pirate kingdom, expelled from the Caribbean area and now settled on Madagascar and other neighboring islands, that did the trading. They bought Madagascar slaves for something like 12 francs and sold them in Barbados for anything between 750 and 1250 francs (Filliot 1974: 119). These "princes of adventure" were "quite at home" in Réunion, and they were regularly seen in Barbados and elsewhere in America (Filliot 1974: 120). After 1720 , the pirate trade was largely curtailed and "official" expeditions took over. There were isolated imports from West Africa before 1728 . Only two of a total of 400 slaves in Mauritius and Réunion together were West African in 1709; excessive costs as well as excessive mortality rates are repeatedly reported (Filliot 1974: 123, 183). The main influx from West Africa fell between 1728 and 1756. In total, however (Filliot 1974: 182), only between 2000 and 3500 West African slaves were imported into the Mascarene region, all between 1702 and 1767, as against Madagascar slaves who were imported "by the thousands" (Filliot 1974: 153). Assuming, generously, that two-thirds of the West Africans in question ended up in Mauritius (cf. Baker and Corne [1982: 186] for a similar division), and making allowance for an increase due to births, a (generous) estimate would be that in 1766, when Mauritius counted 18,100 slaves (Toussaint 1974: 50), those of West African origin numbered around 3500 , or about $20 \%{ }^{5}$

Baker (Baker and Corne 1982) concentrates on the years 1729-1735. He shows that in that period there was a sudden and significant increase in the non-French population of Mauritius (78 at the beginning of 1729 against 1640 by the end of 1735), and that the majority of the imports came from West Africa, due to a few large contingents in 1730 . He sets out in admirable detail all the figures and the documentary sources for those years, which, he argues, were the formative years for MC. He concludes that $\mathrm{MC}$ was affected to a considerable extent by West African influences, which, in his view, explains the similarities between MC (and its offshoot Seychelles Creole) and some Caribbean Creoles, notably Haitian. However, in spite of the real contribution made by Baker's work as regards our knowledge of the early history of the settlement of Mauritius, some doubt remains concerning the linguistic inferences. The main problem arising in the light of Baker's data consists in the fact that no clear West African elements can be spotted in MC, whereas a notable portion of the MC lexicon is of Malagasy origin (Chaudenson 1984: 189-193). The few African words in MC are all East African (Chaudenson 1979b: 228-231). If MC originates from the few years of major West African slave imports and if the form of $\mathrm{MC}$ was determined to any notable extent by the West African slaves, it is hard to see how 
the linguistic result could have become what it is, the more so since Haitian Creole does have verb serialization and predicate clefting as prominent features. The question is, thus, can a plausible scenario be reconstructed that explains why $\mathrm{MC}$ lacks typical West African features in spite of the sudden influx of West Africans in 1730 into a virtually empty island; why MC has a stock of Malagasy words and no West African words; and why MC is more like Haitian than the French Creole of Réunion is? ${ }^{6}$

First of all it must be observed that the French kept slave-trading stations in Madagascar from 1642 onwards, and on the East African coast from 1666 (Toussaint 1974: 27-28). Hull (1979: 207, 209) mentions the French trading post at Ouidah on the Benin coast in West Africa, which was opened in 1671 . He makes out a strong case for the hypothesis that a French maritime patois (pidgin or Creole) developed there in the contact situation between French traders and sailors on the one hand, and natives on the other. (He even distinguishes the earlier Creoles of the Lesser Antilles and French Guyana, which have $k a$ for the present continuative aspect, from the slightly later Creole of Haiti, which has ape [après], like MC.) Given the fact that, contrary to the West African scene, the East African slave trade was largely dominated by the French, it is virtually certain that French-based pidgins developed also, and probably even earlier, in the French-dominated Indian Ocean islands. By 1720 these pidgins may well have evolved into proper Creoles. It must be noted that Creoles often arise in contact situations where the native language is spoken alongside the pidgin or Creole. A case in point is Tok Pisin, which developed in New Guinea after 1860 next to the existing languages (see Mühlhäusler 1979: 56ff.). The new Creole then serves the specific purpose of communication between natives and traders or sailors.

It must also be stressed that it is by no means just the slave population that creates the pidgin or Creole. The Europeans have at times been the main source of pidginization. Sailors, in particular, seem to have spread nautical pidgins across the oceans (cf. Mühlhäusler [1979: 56] on the early history of Beach-la-Mar). It is difficult to deny that a number of features in the French-based Creoles originate from French nautical pidgin: Haitian ki bor 'which board?' for 'where?', MC vire 'turn', gete 'look', large 'release', the colloquial vocative matlo (from French matelot 'sailor'), etc. (see Baissac 1880: 57-59; Hull 1979: 203).

The theory of a French maritime pidgin or Creole, advanced recently again by Hull (1979), applies with equal or greater force to the Indian Ocean area and might thus contain the elements for an explanation of the features shared by all or most of the French-derived Creoles. A maritime "sublanguage" or anyway "sublexicon" is a common phenome- 
non when navigation is a well-developed branch of the economy and social life of a community. In our own days clear specimens are found among Italian and Greek seamen. Some of the specific lexical items originate from the vernacular dialect or dialects spoken by the majority of seamen. Others, in particular those that apply to the movements and steering of ships, were clearly developed at sea and sometimes found their way back into the dialects spoken at home. Baissac (1880: 58) specifically attributes many features of $\mathrm{MC}$ to the dialects of the maritime provinces of France, in particular Bretagne, from which "at least twothirds of the early settlers of the island originated (our old family documents are there to prove it)." It is far from unthinkable that dialectal maritime French provided the lexical basis for, on the one hand, nautical pidgins or even Creoles developed in the contact situations between French sailors and African natives and, on the other, for Creoles emerging in the plantations of the new colonies. The maritime dialects would thus have contributed in two separate but related ways to the relatively high degree of similarity among the French-based Creoles in the world. More detailed study would have to reveal whether the particular similarities of MC and Haitian Creole could be explained along such lines.

This theory will also provide a frame for the explanation of certain salient differences among French Creoles in that it involves inevitable local and temporal differences among the pidgins spoken in the various posts. Hull, as has been pointed out, finds in his theory a satisfactory explanation for the differences between the Caribbean $\mathrm{ka}$ Creoles and the ape Creoles. Analogously, local and temporal pidgin differences can be invoked to explain the undeniable systematic differences between MC and the Creole of Réunion. Baker and Corne (1982) and Hull (1979) argue convincingly that Réunion Creole belongs to a separate "stem" of French Indian Ocean Creoles and is earlier than MC (which is easily understood, given the fact that Réunion was occupied by the French in 1640). The whole matter remains, however, highly speculative, and as long as no more precise details are available on the French and/or pidgins or creoles spoken by the dramatis personae it will probably have to remain that way.

We may perhaps envisage something like the following, highly tentative, scenario for the origin of MC. Around 1700 a French maritime Creole existed in and about the French trading posts in Madagascar. This Creole contained, naturally, a fair number of Malagasy words but was otherwise directly derived from the French spoken by French sailors. At the same time, slightly different (maritime) Creoles had developed or were developing in Réunion and also at Ouidah, the Réunion variety being somewhat more archaic than the other two. When the over 600 West African slaves 
who, as Baker shows, were imported in 1729 and 1730 actually arrived in Mauritius they found (Baker's figures) a group of 50 Malagasy slaves who had been there for a couple of years, 28 newly arrived Indian slaves, and a comparable number of Frenchmen. The Malagasy slaves and the Frenchmen spoke Madagascar Creole, probably with differing degrees of competence and with differing sociolectal colorings (from basilect to acrolect). The West Africans may have had a command of Ouidah Creole but lacked the support of Ouidah Frenchmen. The possibility that there was a brief period of real West African influence in the language spoken in Mauritius cannot be excluded, given Baker's data, but the linguistic evidence strongly suggests that whatever such influence there may have been was swamped and stamped out by the vast numbers of Madagascar slaves arriving after 1735, and by the continuing presence of French speakers of Madagascar Creole. On the other hand, given the dominating presence of the French in Madagascar and thereabouts and their subordinate role vis-à-vis the other Western European powers in West Africa, it is not at all unthinkable that certain features of the Madagascar pidgin or Creole were transferred to West Africa and hence to the Caribbean.

Baker (Baker and Corne 1982: 255, 257) wants to draw some support from the fact that the area of the capital Port Louis where the slaves were given living quarters is called "Camp Yoloff," after the Yolof people (whose language is Wolof) in Senegal. Filliot (1974: 185) comments:

Les Yolofs (Ouolofs) et "Bambares" du Sénégal accompagnés des "noirs de Guinée" arrivèrent donc en plus grand nombre que les captifs du Golfe de Bénin. Un quartier de Port Louis porte encore le nom d'un de ces groupes d'esclaves: le "Camp Yolof". Sans faire de la toponymie aventureuse, l'expression montre que ces "Yolofs" avaient été remarqués.

However, as Baker himself notes, the name "Camp Yoloff" does not occur on any eighteenth-century map or in any document of that period. The first attested occurrence of the name is in the 1830s. Baker might have added that the district of Port Louis in question is called "Camp (Champ) des Noirs" on older maps, such as the 1814 London edition of the map by Lislet Geoffroy, and that according to Bernardin de SaintPierre (1983 [1773]: 115) the Camp des Noirs was occupied by Indians from Pondichery ("d'une teinte plus foncée que les insulaires de Madagascar qui sont de véritables Nègres"). The earliest map I have found with the name "Camp Yoloff" on it is the 1848 map by V. Devaux (copied in 1854 by $\mathrm{J}$. Maisonneuve). In spite of the late appearance of the name "Yoloff," Baker is inclined to let the name date "from the period 1730-1735 when Yolofs were the most numerous ethnic group among the slave population" (Baker and Corne 1982: 257). It is, however, 
equally possible that the name was given around the time of its first appearance in the documents, around 1835, when slavery was abolished. One might even surmise that in renaming the Camp des Noirs one wanted to pay a tribute to the Yolofs, who "avaient été remarqués."

The case of Camp Yoloff inevitably brings to mind the name of the village of Surinam, on the south coast of Mauritius. According to Hollingworth (1961: 18) it was a nineteenth-century sugar estate, named after the Dutch colony that was known for its sugar production. Here, although Hollingworth makes no mention of it, a tribute may have been implied to the "young man from Surinam," who, around 1695, "instructed the [Dutch] settlers how to produce cane-sugar with the syrup" (Napal 1980: 35). The name "Surinam" likewise appears for the first time on the 1848 map by Devaux. In contrast to these two names, we have the name "Riambel" for a location close to Surinam in Mauritius, which, according to Hollingworth (1961), is derived from the Malagasy Ariambel 'sunny coast', and which appears as "Arienbelle" on the map made by Abbé de la Caille in 1753. It would thus appear that place names do not provide much evidence in favor of West African linguistic influence since the names with obvious West African or Caribbean connections appear too late in the documents, whereas the Malagasy-derived names turn out to be genuine.

Our position is thus not far removed from that of Goodman (1964) and Hull (1979), although it must be recognized that Baker has contributed essentially to our insight by bringing to bear precise data on the settling of Mauritius in the early years and thus forcing us to make less blurred reconstructions of the linguistic situation in the period concerned than we would otherwise have made. The reconstruction by Hull, however, needs to be extended with a theory about Madagascar and Réunion maritime pidgins and Creoles, and about possible interactions. In the main, our position is that MC was not influenced to any significant degree by West African languages or by whatever French pidgin or Creole was spoken in West Africa, and that MC goes back directly to a hypothetical Madagascar Creole that originated as a contact Creole between Madagascar natives and French traders and/or sailors.

\section{Absence of verb serialization in MC}

Although the phenomenon of verb serialization has been observed by many linguists in many languages, no general definition has been provided (but see Seuren 1990a, 1991). The phenomenon is illustrated by the following sentences taken from Sranan, the Creole of Surinam: ${ }^{7}$ 
(1) a. A e go tyari switi-mofo gi me he PRES will carry sweet-mouth give me 'He will bring sweets for me'

b. A trowé a batra go na abrasey he throw the bottle go to other side 'He threw the bottle to the other side'

c. A ben kan luku go na liba he PAST can look go to river 'He could see toward the river'

d. Kofi fringi a tiki trowé naki Ambi Kofi fling the stick throw hit Amba 'Kofi threw the stick away and hit Amba'

In all cases the subject of the serial verb is deleted. The deletion can be controlled by the subject of the higher clause, as in (1a), or by its object, as in (1b), or the controller is an inherent object in the verb, as in (1c): 'so that his eyesight went as far as the river'. ${ }^{8}$ (1d) combines subject and object control of the deletion: subject control for trowe 'throw away', and object control for naki 'hit'.

Sentences such as these occur in all Caribbean Creoles, as well as in many languages of the Eastern part of West Africa. It is commonly assumed, and with good reason, that the Caribbean Creoles have inherited their serial verbs from West Africa. A precise definition of serialization, however, is never given. ${ }^{9}$ It is important, nevertheless, to distinguish verb serialization as a grammatical phenomenon from other forms of verbal serial stringing, such as the well-known verbal clusters in German or Dutch, or the French causative constructions. These are adequately described in terms of the cyclic rule of predicate raising, ${ }^{10}$ and it would be wrong to think of verb serialization here. If the claim made in Bickerton $(1981,1984)$ that serialization is a universal feature of all Creole languages is to be at all falsifiable and not vacuously applicable (by dint of defining as Creole only those languages that have serial verbs), a sufficient number of defining criteria must be provided.

As has been said, an attempt has been made in Seuren (1990a, 1991). There it is proposed that verb serialization occurs when there is a tenseless embedded object clause, without negation and without any complementizer, which does not occupy a position defined in the lexical argument structure of the main verb: the object clauses in question are instances of pseudocomplementation, frequently found with verbs of movement (as in English go fishing, where fishing is an original object clause but not occupying a canonical lexical object position, as the verb go is intransitive). Moreover, the subject term of the pseudocomplement object clause 
is deleted under higher control (as shown above in connection with [1a]-[1d]). If no other rules of cyclic syntax apply, such as predicate raising, the result is the kind of verb serialization that attracted the attention of Africanists around 1950 and gave rise to the fast-growing literature on the subject nowadays.

The question now is, does MC have verb serialization? In one case one might perhaps think of serialization. MC knows the expression koz mãti, composed of the two verbs koze 'say, speak' and mãti 'lie'. Thus the MC sentence

\section{(2) Li ti pe koz mãti he PAST CONT speak lie 'He was lying'}

might be thought to represent serialization, were it not that the standard features of serialization are absent, and a different analysis quickly presents itself in terms of a normal and productive $\mathrm{MC}$ construction. Thus, it is never possible in $\mathrm{MC}$ to place a form like mãti as a more or less loose adjunct after an otherwise complete sentence - a possibility that is typical of verb serialization. Thus we do not find (3a), but we do find $(3 b)$ :
a. *Li ti pe koz avec mwa mãti he PAST CONT speak with me lie
b. Li ti pe koz mãti avec mwa he PAST CONT speak lie with me 'He was lying to me'

But it is possible to quantify mãti by means of appropriate quantifiers like buku 'many':

Li pe koz buku mãti

he CONT speak many lies

'He habitually speaks many lies'

This speaks against serialization. Moreover, it is normal in MC to use verbs as past participles with the status of mass nouns, when no separate lexical item is available. Thus the word mãti means not only 'to lie' but also 'lies', as a mass noun. Consequently, the sentence

\section{(5) Mo pa kõtã mãti \\ I not like lie}

mens not only 'I don't like to lie' but also 'I don't like lies'. 'The same goes for a number of other verbs, such as zwe 'play/games', zure 
'swear/swear words'. Sentence (2) thus naturally accepts an analysis where mãti is the internal object of the verb koze: 'he was speaking lies'.

Note also that MC lacks the use of original serial verbs for what have become prepositions (such as Sranan gi, which has become the dative preposition, as pointed out above). Nor does MC have the serial 'exceed' comparative found in most Caribbean Creoles (Alleyne 1980: 13). Our conclusion must therefore be that $\mathrm{MC}$ has no verb serialization. Serialization is as alien to $\mathrm{MC}$ as it is to European languages. ${ }^{11}$

\section{Absence of predicate clefting in MC}

"Predicate clefting" is the term used for the distinctive form of clefting found in the Caribbean Creoles (Alleyne 1980: 12, 103-104) and in West African languages, in particular those of the Kwa group (Alleyne 1980: 171-173), where the predicative verb or adjective is "clefted out" by means of a grammatical construction of the type 'it is ... that'. Semantically, cleft constructions specify a topic, that is, what the sentence is about, and provide a comment, that is, an answer to a question raised about the topic (Van Kuppevelt 1991). They also presuppose the reality of the topic. Thus, in a sentence like 'It is John that wrote the letter', the topic is the one who wrote the letter, the (usually implicit) question raised is 'Who is the one that wrote the letter?', and the comment or answer is that the one who wrote the letter is John. The constituent denoting the topic is typically unaccented, whereas the comment carries emphatic or contrastive accent. Predicate clefting is a form of clefting, absent in European languages, whereby the new information provided, the comment, consists of a predicate and the topic is a property, state, or action expressible by means of a predicate.

In the European languages predicate clefting cannot be expressed through a construction of the type 'it is ... that'. Only alternative grammatical means, such as pseudoclefting ('What John is is IMPOLITE'), or mere emphatic or contrastive accent ('John is IMPOLITE') can be used to express the meaning of predicate cleft sentences. What is distinctive for the Caribbean Creoles and some West African languages is that they do allow for grammatical clefting of the predicate. However, grammatical predicate clefting is invariably marked by the fact that a copy of the clefted predicate occurs in the topic constituent. Examples are the following:

(6) a. Sranan:

$\mathrm{Na}$ bigi yu futu bigi

be big your feet big

'Big is what your feet are' 
b. Sranan:

$\mathrm{Na}$ fufuru a fufuru en, a no bay is steal he steal it be not buy

'What he did was STEAL it, not BUY'

c. Haitan:

Se mãže m ap mãže

be eat I CONT eat

'What I am doing is eat'

Such sentences are not isomorphically (i.e. with maintenance of grammatical structure) translatable into MC.

Corne (Baker and Corne 1982: 85-89) argues that MC does have predicate clefting (his "double predication"), but the argument is not convincing. Corne presents two classes of cases where, according to him, double predication occurs. The first batch (1982: 85) consists of the following sentences (I leave out the two examples from Seychellois because they come from an elderly speaker resident in New Zealand, and also the one example taken from Rodrigues: Zape mem, to pa ko zape? 'Bark, can't you bark?', which is simply a case of left dislocation, not of clefting):

(7) a. Bate li kapav bate

beat he can beat

'he can beat as much as he likes (it will be in vain)'

b. Rode $\mathrm{Zã}$ ti ape rode so lisiẽ, me li pa fin seek John PAST CONT seek his dog but he not PERF truv li

find it

'John was really searching for his dog, but he couldn't find it'

c. Debat li ti debat, me vag-la ti resi zet fight he PAST fight but waves-the PAST succeed throw li ã-deor brizã

him beyond reef

'Struggle as he would, the waves managed to throw him beyond the reef'

d. Malad li ti ape malad, me dokter napa ti sick he PAST CONT sick but doctor not PAST kapav sogn li can treat him

'Although he was getting seriously ill the doctor could not treat him'

The second batch (1982: 86) has the typical structure napa ... ki 'it is not ... that': 
(8) a. Napa tini ki li tini

not hold that he hold

'He/it holds fast'

(Baissac 1880: 199)

b. Napa vane ki li vane

not run that he run

'Was that running he did!'

(Baissac 1880: 199)

c. Napa rode ki zot ti rode, ler Zan ti perdi not seek that they PAST seek when Jeanne PAST lose

so lasen lor

her chain gold

'They really searched diligently when Jeanne lost her golden chain'

d. Napa bure ki voler-la ti bure, me lapolis ti not run that thief-the PAST run but police PAST resi may li

succeed catch him

'The thief ran as fast as he possibly could, but the policeman managed to catch him'

It must be noted, first, that Chaudenson (1984: 173) speaks of "de faits très marginaux." In fact, when I sprang sentences of type (7) or (8) on native speakers of $\mathrm{MC}$, the reaction was invariably one of total perplexity. I therefore feel inclined to agree with Chaudenson that cases as given in (7) and (8) are indeed marginal, or even obsolete. The forms ape in (7) and napa in (8), for modern MC pe and pa, respectively, indicate that these sentences do not belong to $\mathrm{MC}$ as it exists today. Moreover, they are not examples of predicate clefting in the sense defined above. Corne's term "double predication" obscures certain essential semantic distinctions. The fronting and copying of the predicates in (7) is an intensifying device, with none of the semantic characteristics of clefting. The examples of (8) have a special idiomatic and metalinguistic flavor. In fact, Baissac observes, in connection with (8b), "it is an elliptical form for napa apele vane sa ki li vane - 'it isn't called run what he ran'." They are, moreover, clearly restricted to the one rigorously defined structure napa ... ki. Corne acknowledges this point (Baker and Corne 1982: 87) when he says that the Ndyuka (a Maroon Creole in Surinam) sentence Ná kii mi dda kii tu pakila 'my father did not kill the two peccaries (he merely wounded them)' stands 'in sharp contrast to the superficially similar MC construction with napa+predicate head $+k i+$ sentence." Yet, in the same breath he asserts, "It appears 
then to be the case that in spite of minor local differences, there is nothing in IdeFC [i.e. Isle de France Creole; P.S.] that is not parallelled by similar structures in other Creole languages." It would seem, on the contrary, that MC lacks precisely the form of predicate clefting exemplified by the Ndyuka sentence, and by the sentences of (6). In other words, the form of predicate clefting that is so typical of the Caribbean Creoles and of some West African languages is absent from modern MC, as it is from Seychellois, from Rodrigues Creole, and from Réunion Creole. ${ }^{12}$

However, given the data provided by Corne and Baissac, the question arises of the origin of the constructions given in (7) and (8). They are not convincingly reminiscent of anything in French. The sentences of (8) bear the hallmark of a construction that has become idiomaticized, originating from an earlier more productive and less idiomatic expression type involving a real cleft construction. The same goes for (7), which looks like an instance of semantic specialization when compared with real clefts. One might therefore venture the hypothesis that the cases in question may originate from an original predicate cleft construction, which, however, was doomed to disappear, being alien to the rest of the language. If this hypothesis is correct we may have here a single isolated case of West African influence, bearing out the shortlived dominant presence of West African slaves in the early settlement years of Mauritius. But it must be stressed that this possible West African remnant has now disappeared from MC and all other Indian Ocean Creoles.

The only form of clefting possible nowadays in $\mathrm{MC}$ is the clefting of NPs and of adverbials. But the form most frequently found is subject clefting:
a. Mwa ki fin fer sa me that PERF do that
'It is me who did that'
b. Se mwa legater lepep
be me representative people
'It's me that is the people's representative'
(Virahsawmy ZM)

c. Se ãbasader $\mathrm{ki}$ fin gagn lodiãs premye be ambassador that PERF get audience first 'It is the ambassador who was ushered in first' (Virahsawmy ZM)

The grammatical form of subject clefting is defined by $s e . . k i$, where either se or $k i$, but not both, may be left out. ${ }^{13}$ Object clefting is possible but relatively infrequent (unlike the Caribbean and West African languages): 
(9) d. (Se) sa loto-la ki mo fin vãde

(be) that car-the that I PERF sell

'That is the car that I have sold'

We conclude that predicate clefting is not a feature of modern MC, but that it may have been faintly present in older forms of MC. Predicate clefting must therefore be discounted in any argument aiming at establishing a major West African influence in MC. It must likewise be discounted in any argument trying to establish that predicate clefting is a Creole universal.

\section{The verb apocope rule}

Verb apocope (VA) is the name we give to the phenomenon, commented upon by all authors on MC, that most MC verbs shed their final vowel, almost always $-e$, in certain environments or modify the verb in other ways. ${ }^{14}$ Not all verbs are subject to VA. Verbs not ending in $-e$ do not take VA, except vini 'come' and, doubtfully, sorti 'go out', and the auxiliary verb fini 'end', which serves as marker of resultative-perfective aspect. Verbs ending in Consonant $+y / w+e$ (e.g. abitye 'be used to', kontinye 'continue', zwe 'play') do not take VA. Nor do, for example, aste 'buy', aksepte 'accept', mõtre 'show', ule 'want'. Some verbs show morphophonemic alternation: tõbe/tom 'fall', rãtre/rãt 'enter', vãde/van 'sell', tãde/tan 'hear', dimãde/diman 'ask', reste/res 'live, stay', etc. Ete 'be' has the null morpheme $\emptyset$ as its truncated variant.

Most other French-based Creoles also drop the final vowel of verb forms, but the conditions differ considerably (Stein 1984: 73-74). We shall concentrate here on the form of verb apocope that occurs in MC (and almost identically in Seychellois) and not in any other French Creole.

Baissac (1880) repeatedly formulates the following rule: when a verb is followed by a complement, final $-e$, sometimes final $-i$, is dropped. Taking into account possible differences that may have arisen between 1880 and now, this rule is in principle, yet not quite, correct. The final answer to the question of what conditions the application of VA has not, so far, been provided. ${ }^{15}$

Let us consider some data. In the following pairs full and truncated verb forms are contrasted:

$$
\begin{aligned}
& \text { a. Mo fin mãze (*mãz) } \\
& \text { I PERF eat } \\
& \text { 'I have eaten' }
\end{aligned}
$$


b. Mo fin mãz (*mãze) diri-la I PERF eat rice-the 'I have eaten the rice'

(11) a. To kõtã mãze (*mãz) you like eat 'You like to eat'

b. To kõtã mãz (*mãze) diri you like eat rice 'You like to eat rice'

(12) a. Zwazo sãte (*?sãt) boner birds sing early 'Birds sing early' (Virahsawmy 1967: 66)

b. Li fin mãz (*?mãze) boner zordi he PERF eat early today 'He has eaten early today' (Virahsawmy 1967: 65)

(13) a. Li pu vini (*?vin) dimẽ he FUT come tomorrow 'He will come tomorrow' (Virahsawmy 1967: 98)

b. Bolfam-la fin vin (*?vini) tar lakaz woman-the PERF come late home 'The woman has come home late' (Baker 1972: 149)

a. Li vini (*vin) rarmã he come rarely 'He comes rarely' (Virahsawmy 1967: 98)

b. Mo ti lev (*?leve) tar I PAST get up late 'I got up late' (Baissac 1880: 6)

What appears from these sentences is that one condition for the application of VA is the presence of a nominal complement after the verb, as Baissac said, no matter whether the verb is finite or infinite. The complement need not be a direct object. It may also be an indirect object or a measure phrase:

a. Nu ti galup (*galupe) èn mil

we PAST run one mile

'We ran one mile'

(Virahsawmy 1967: 65) 
b. Sizi fin avoy (*avoye) so fami èn kart Suzy PERF send her family a card 'Suzy has sent her family a card'

(Baker 1972: 105)

Note, however, that VA does not operate when a subject follows the verb:
a. Ti vini (*vin) bonom-la?
PAST come man-the
'Did the man come'?
b. Kã ti vini (*vin) bonom-la? when PAST come man-the 'When did the man come?'

(12)-(14) show that VA does not operate when the verb is followed by a time adverbial, except when the time adverbial functions more as a manner adverbial, as in (12b), (13b), (14b). ${ }^{16}$

Manner adverbs clearly induce VA:
a. Tõtõ ti vin (*vini) dã loto
uncle PAST come
by car
'Uncle came by car'
b. Li mars (*marse) kuma èn torti
he walk like a tortoise
'He walks like a tortoise'
(Virahsawmy 1967: 100)
c. Li mars (*marse) dusmã
he walk slowly
'He walks slowly'

Place adverbials may induce VA, depending on their semantic funtion. If a place adverbial is a further specification of a verb that semantically implies the category "place," as in the sentences of (18), the tendency is for VA to apply. But if a place adverbial functions as a semantic operator taking the whole proposition as its scope, VA tends not to apply and the full form appears, as in (19). It must be stressed, however, that for cases of this kind native judgments vary a great deal and are not consistent, precisely because the interpretation is highly context-dependent:

(18) a. Nu fin mars dã simẽ progrè

we PERF walk in road progress

'We have taken the road of progress'

(Virahsawmy ZM)

b. Mo ti pe asiz divã mo laport

I PAST CONT sit in front of my door

'I was sitting in front of my door'

(Baker 1972: 107) 
c. Mo papa pe al laba my dad CONT go there

'My dad is going there'

(Virahsawmy 1967: 101)

d. Mo tom dã dilo

I fall in water

'I fall into the water'

(Baissac 1880: 42)

e. Zot pa res isi

they not live here

'They do not live here'

(19) a. Nu fin marse dã simẽ progrè

we PERF walk in road progress

'We have walked on the Road of Progress'

b. Mo pa ule mãze dã simẽ

I not want eat in road

'I do not want to eat in the street'

These data show clearly that VA is linked up with VP-constituency. The first generalization is that VA applies when the verb is not VP-final not much different from what Baissac said. It is well known that adverbials waver as to their constituency: sometimes they are and sometimes they are not part of VP, depending on often subtle and usually contextdependent semantic distinctions (see Seuren i.p.: section 3.5 for ample discussion). This wavering is directly reflected in the conditions for VA application. There are, however, a few complications.

One complication arises in cases where there is an opposition, in the combination of verb and object, between a collocation reading that is to some extent lexicalized and one where the combination is considered free and original. When such an opposition is felt to exist VA tends not to apply for the "free" reading, thus marking the fact that the lexicalized reading is not the intended one. The difference between the two readings is akin to what is observed in English expressions like keep tabs on, take care of, take umbrage at, etc., whose syntactic behavior differs from "free" combinations in various ways. For example, passives like She was taken care of are impossible for "free" readings. Thus, both (20a) and (20b) are good $\mathrm{MC}:{ }^{17}$
a. U pa gagne frè you not get cold 'One (normally) doesn't suffer from cold'
b. U pa gagn frè you not get cold
'You are not suffering from cold (now)' 
Another complicating factor is that reduplicated verbs never drop their final vowel: ${ }^{18}$

a. Zot ti pe mars-marse (*mars-mars) lari they PAST CONT walk-walk street

Deforz

Deforges

'They were strolling along Deforges Street'

(Baker 1972: 105)

b. Zot fin-fini (*fin-fin) devine you PERF guess

'You HAVE guessed it'

(Virahsawmy ZM)

c. Lepep fin-fini (*fin-fin) don u tu puvwar people PERF give you all power 'The people have definitely given you all power' (Virahsawmy ZM)

A further complication is brought about by the fact that most writers make exception for passives in the application of VA. MC has a nonmorphological passive, like many other Creoles, but, unlike most other Creoles, it also has a completely developed agent phrase, with the prepositions ar, ek, or avek 'with, to'. Baissac (1880: 42) states categorically that VA does not apply to passive verbs (he uses the now antiquated preposition $a v$ for the agent phrase):

(22) Tu lanwi mo disã ti mãze av pinez all night my blood PAST eat with lice 'All night my blood was eaten by lice'

This is now no longer so: in modern MC VA applies with passive verbs before the agent phrase. Corne (Baker and Corne 1982: 69) gives the following modern $\mathrm{MC}$ passive sentence:

(23) Latet torti fin ramas ãba lakok head tortoise PERF pull up below shell

'Tortoises's head is pulled up underneath his shell'

Moreover, I found the following sentence accepted:

(24) Sa fin explik mwa that PERF explain me

'That has been explained to me'

This shows that passive sentences follow VA normally, although such cases are rare. 
This leaves only one complication to be solved. It is brought about by clausal complementation. When the embedded clause is fully tensed VA does not apply:

a. $\mathrm{Al}$ gete (*get) kisanla sa

go see who that

'Go and see who that is'

(Virahsawmy ZM)

b. To pa kone (*kon) ki ete akolad? you not know what be accolade

'Don't you know what an accolade is?'

(Virahsawmy ZM)

c. Li ti truve (*truv) ki mo pa kapav marse he PAST see that I not can walk 'He saw that I couldn't walk'

Even when the subject of a tensed object clause has been raised VA does not apply:

(26) To truve (*truv) Kapitèn kimanyer li onet you see Captain how he honest

'You see how honest the captain is'

(Virahsawmy ZM)

Nor does it with an infinitival complement right after $\mathrm{V}$ but preceded by a complementizer:

(27) Li pe lite (*lit) pu dibut lor so propre lipye he CONT fight for stand on his own feet 'He is fighting to stand on his own feet'

But with infinitival complements without a complementizer one finds that VA sometimes does and sometimes does not apply:
a. Zot dispoze $(*$ dispoz) fer tu depãs they disposed make all expenses 'They are willing to take on all expenses' (Virahsawmy ZM)
b. Li ti degaze (*degaz) mãze he PAST hurry eat 'He ate in a hurry'
c. Mo pu galupe (*galup) vini
I FUT run come 'I'll come running' 
d. To pu marse (*mars) ale you FUT walk 'You will go on foot'

(29) a. Li vin (*vini) mãze

he come eat

'He comes to eat'

b. Papa pe al (*ale) marse

Dad CONT go walk

'Daddy is going on foot'

c. Mo fin $\tan (*$ tãde) dir sa

I PERF hear say that

'I've heard that said'

d. Bizẽ kon (*kone) rekõpãs lepep

need know reward people

'One must know how to reward the people'

(Virahsawmy ZM)

e. Li sey (*seye) kasyet so col

he try hide his collar

'He tries to hide his collar'

(Virahsawmy ZM)

f. li $\operatorname{rod}(*$ rode) tãde

he try hear

'He tries to hear'

g. lapli pe komãs (*komãse) tõbe

rain CONT begin fall

'It is beginning to rain'

h. les dres (*drese) to kostim

let iron your suit

'Have your suit ironed'

The contrast in VA application between the sentences of (28) and those of (29) is extremely intriguing from the point of view of theoretical grammar, and, by implication, for certain recent claims (e.g. Bickerton 1984) concerning an innate "core" grammar that would determine the grammatical makeup of "real" Creole languages. For it seems that the difference between (28) and (29) is effortlessly accounted for by assigning to the verbs in question certain rule features in virtue of which they induce certain syntactic rules leading to embedded VPs for the cases of (28) but to complex V-islands of the type ${ }_{V}\left[{ }_{v}\left[f_{i n}\right]_{V}[\right.$ mãze $\left.]\right]$ for sentences as in (29). The rules involved are all well known from the theory of transformational grammar, especially the tradition of generative semantics, now semantic syntax, but they fall outside the scope of "core" 
grammar as envisaged in Bickerton (1984), and they are clearly at odds with the whole philosophy of grammar underlying that approach. The neatness of the grammatical solution to this problem is thus a strong argument against "core" grammar theories as developed by Bickerton.

Pending the treatment of the cases of type (28) and (29) in the following section, we can now formulate the verb apocope rule as follows:

\section{Verb apocope rule:}

Whenever V is [+ VA] and is not either VP-final or followed by VP or $\mathrm{S}, \mathrm{V}$ is truncated. Otherwise the full form is used.

A final comment is in order about the copula verb in MC. MC shares with many Creole and non-Creole languages the feature of copula deletion under certain conditions. How relevant this is for the study of Creole linguistic universals is hard to say, since the conditions for copula deletion vary widely, ${ }^{19}$ and also because no survey is available of copula deletion in a sufficiently large sample of languages, Creole or non-Creole. In MC the main condition seems to link up directly with the VA rule. As indicated above, at the outset of this section, the full form of the MC copula is ete. Under the same conditions as hold for VA ete is reduced to $\emptyset$. Consider the following:

(30) a. Ki kote Amin ete aster?

what side Amin be now

'Where is Amin now?'

b. $\mathrm{Ki}$ ete sa?

what be that

'What is that?

c. $\mathrm{Ki}$ manyer Moris ti ete lõtã?

what manner Mauritius PAST be in the past

'What was Mauritius like in the past'

(Baker 1972: 126)

(31) a. Amin ki kote aster?

Amin what side now

'Where is Amin now?'

b. Moris ti kuma èn paradi

Mauritius PAST like a paradise

'Mauritius was like a paradise'

(Baker 1972: 126)

c. Li nepli la

he no longer there

' $\mathrm{He}$ is no longer there' 
d. Sa zãfã-la ti malẽ that child-the PAST clever

'That child was clever'

e. Kisanla to siperyer?

who your superior

'Who is your superior?'

f. Arlet ti ar mwa

Arlette PAST with me

'Arlette was with me'

(Baker 1972: 104)

g. Sa later-la pu Tõtõ Bolo

that land-the of Uncle Bolo

'That land belongs to Uncle Bolo'

(Baker 1972: 104)

In equative WH-questions, such as (30b) or (31e) (compare also [25a] and [25b] given above), ete is optional. This is a direct consequence of the fact that in such questions either the WH-constituent or the topic-NP can be taken as subject: as has been shown, VA does not apply when V is directly followed by the subject (see [16] above), but VA does apply when $\mathrm{V}$ is directly followed by the predicate nominal. As far as I have been able to observe, ete varies with the $\emptyset$ form of the copula precisely along the lines of the VA rule. It seems sensible, therefore, to regard the null morpheme as the truncated variant of ete. ${ }^{20}$

\section{Verb complementation}

In the preceding section it has been claimed that the fact that VA does not apply in the sentences of (28), whereas it does in those of (29), is explained by associating the verbs in question with different syntactic rules, and that the rules involved are well known from transformational grammar. Let us now have a closer look.

There is a well-known rule in TG that is usually called "equi-NP deletion," but "subject deletion" (SD) in Seuren (1985: 131, i.p.). This cyclic rule involves the deletion of the subject of an embedded clause under certain conditions of referential identity with the "controller," which is either the higher subject or the higher (indirect) object. Thus, the English sentence Jack wanted to leave is derived from an underlying ' $\mathrm{Jack}_{\mathrm{i}}$ wanted [ $\mathrm{x}_{\mathrm{i}}$ leave]', where the variable $x_{i}$ guarantees referential identity with $\operatorname{Jack}_{\mathrm{i}}$. SD is induced by the controlling verb, in this case the verb want. The general format of the cyclic rule of subject deletion (SD) is as follows: 
(32)

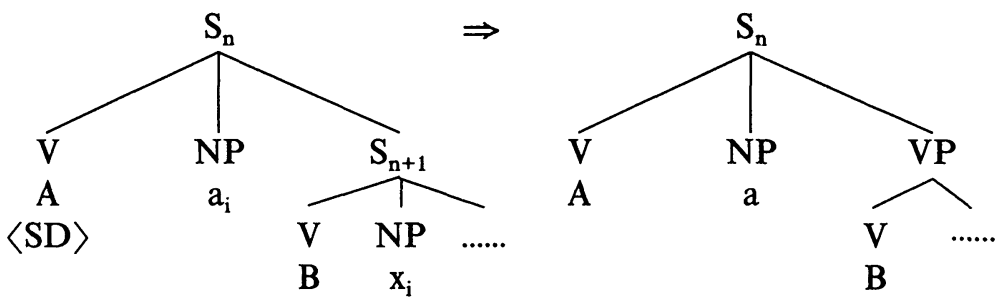

The rule is formlated under McCawley's (1970) VSO hypothesis, which simplifies the treatment considerably. The subject of $S_{n}, a_{i}$, correlates with the subject of $S_{n+1}$, that is, ${ }_{N P}\left[x_{i}\right]$. Since the $V$ of $S_{n}$ is marked for SD (rule features are placed between angled brackets) and the condition of identity between the controller $\left(\mathrm{a}_{\mathrm{i}}\right)$ and the lower subject is met, the subject of $S_{n+1}, x_{i}$, is deleted on the cycle of the controlling verb, that is, the $S_{n}$ cycle. In virtue of the general principle that an $S$ whose subject term is removed by a cyclic rule is relabelled VP (Seuren 1985: 128), $S_{n+1}$ is relabelled VP. The eventual NP-VP structure is brought about as a result of the tense routine, the standard treatment of the two tenses leading automatically from VSO to NP-VP (see section 7 below). Tenses are considered to be higher abstract predicates, above $S_{n}$. The lowest tense $\left(t_{2}\right), \emptyset$ or PERF or the continuative aspect pe, or the 'prior-to' operator deza induces lowering (L) into its argument-S. The highest tense $\left(\mathrm{t}_{1}\right)$, PRES or PAST, induces subject raising of the subject term of $S_{n}$ (which thus becomes VP) and lowering of the tense predicate into that VP (for detailed discussion, see Seuren 1985: 128-130, i.p.: section 2.7.4.2.1.)

This analysis applies to all sentences of (28). In all these cases the embedded clause (VP) is to be regarded as an object-VP. Thus, for (28c), the meaning is something like 'I will run my coming', and for (28d) 'you will walk your going'. One might think of a VP-external adjunct for these two sentences, with a vaguely purposive meaning: 'I will run in order to come' and 'you will walk in order to go', but such an analysis is at odds with the fact that manner adverbials come after, not before, the infinitives:
a. Mo pu galupe vini vit I FUT run come fast 'I will come running fast'
b. *Mo pu galup(e) vit vini
a. To pu marse ale dusmã you FUT walk go slowly 'You will go slowly on foot'
b. *To pu mars(e) dusmã ale

This explains why the sentences of (28) do not undergo VA. 
The sentences of (29) differ from those in (28), as we have seen, by the application of VA. This difference is accounted for by assigning to the higher verbs in question the rule feature $\langle P R\rangle$, predicate raising. This rule is well known in the syntax of many languages. A striking feature of this rule is that the verbs that induce it are nontrivially similar in the languages of the world. It is hardly a coincidence that the Dutch and German equivalents of all the verbs in question in (29) are also PR-inducers: 'come', 'go', hear', 'know how to', 'try', 'seek', 'begin', 'let', 'make' (for a detailed discussion see Seuren 1985: 79-86, 172-188). In French it is mainly the equivalents of 'hear', 'let', and 'make' that induce PR. It thus seems that MC has innovated on this score, but the innovation is clearly within orthodox boundaries of universal grammar (not, of course, "core" grammar). Whether this innovation originates from a preexisting African source or set of sources, or whether it is spontaneous and thus due to linguistic universals that should be assumed to be somehow innate, is a question that cannot be decided now.

The general format of the cylic rule of predicate raising (PR) is as follows:

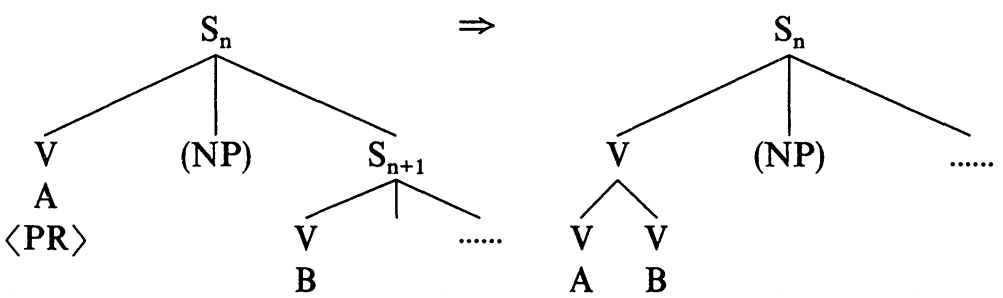

That is, on the $S_{n}$ cycle the $V$ of $S_{n+1}$ is detached and reattached, by (right or left) adoption, ${ }^{21}$ to the copy of the PR-inducing V-node inserted between it and $S_{n}$. According to the general principle (Seuren 1985: 128), an $\mathrm{S}$ or VP node is pruned if it loses the immediately dependent $\mathrm{V}$ because of raising. Here this means that the node $S_{n+1}$ is abolished and all remaining material of $S_{n+1}$ is reattached to $S_{n}$. The result is as shown.

For (29a), where vini has the rule features SD and PR, we get the following derivation: 


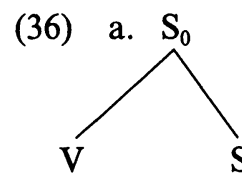

PRES

$\langle\mathrm{SR}, \mathrm{L}\rangle$

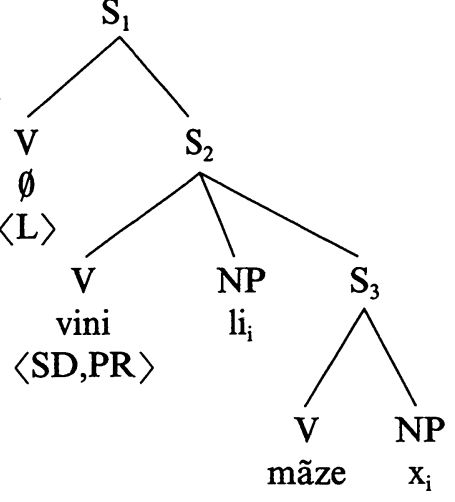

$\mathrm{PR} \Rightarrow \mathrm{c} . \quad \mathrm{S}_{0}$

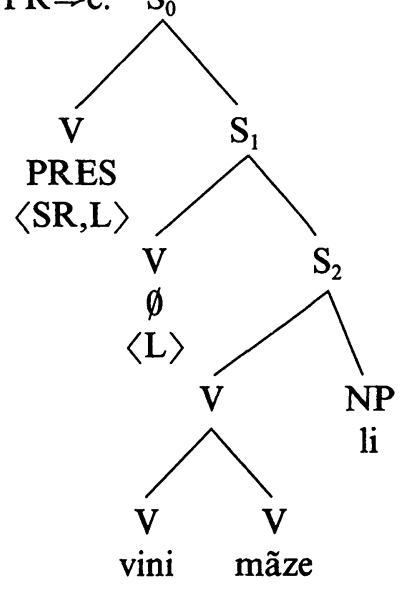

$\mathrm{SR} \Rightarrow$ e. $\quad \mathrm{S}$

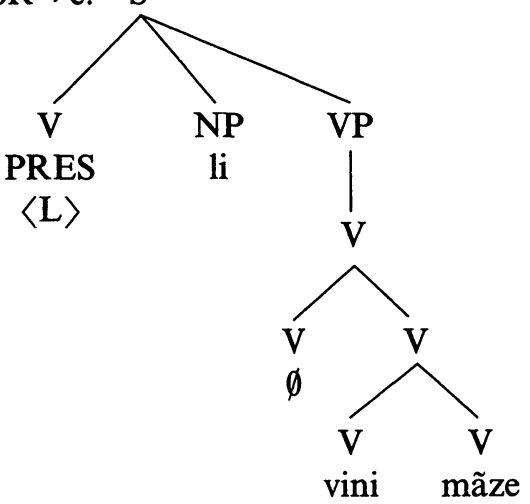

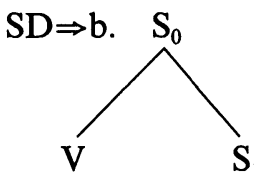

PRES

〈SR,L〉

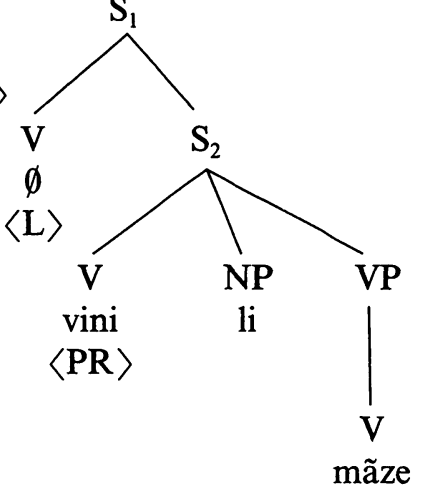


(Note that [36] conforms to [53] below, which specifies the tense routine.) The VP in (36e) and (36f) represents the old $S_{1}$. It is clear that, postcyclically, VA now applies to vini, since vini is [+VA] and not VP-final nor followed by VP or S. Hence (29a). Likewise for (29b)-(29g).

The sentences $(29 c)$ and $(29 h)$ present the further feature that the lower clause is passive, that is, without a subject-NP. It is normal for all languages that have a morphological passive and the cyclic rule PR that no passive morphology appears under PR. Thus, for example, the French

(37) Il a fait tuer le prisonnier par les soldats

he has made kill the prisoner by the soldiers

'He had the prisoner killed by the soldiers'

has the verb tuer in the morphological shape of an active form, but syntactically and semantically tuer is passive, as appears from the agent phrase. For MC, however, this consideration remains vacuous, since it has no passive morphology anyway. For the two sentences in question, the rule SD does not operate as there is no lower subject to delete.

To avoid the impression that this analysis has been thought up only to acount for the facts shown in (28) and (29) we shall now show that there are compelling independent reasons for assuming that PR is an active rule in MC syntax. It is seen to operate particularly clearly with the verbs fer 'cause, make, do', les 'let, allow' and tãde 'hear', all three well known in many languages (French, Italian, Dutch, German, Japanese, Uto-Aztecan, Tagalog, etc.) for their property of inducing PR, either obligatorily or optionally. Consider the following cases of grammatical and ungrammatical PR-application:

(38) a. Mo kuzẽ pu fer mwa gagn èn bõ travay my cousin FUT make me get a good job

'My cousin will get me a good job'

b. *Mo kuzẽ pu fer gagn mwa èn bõ travay

(39) a. Mo fin tan so papa dir sa nuvel-la

I PERF hear his father say that news-the 'I've heard his father tell that news'

b. Mo fin tan dir so papa sa nuvel-la

(40) a. Serzã-la pa ule fer vin èn dokter

Sergeant-the not want make come a doctor

'The sergeant doesn't want to call a doctor'

(Virahsawmy $\mathrm{Li}$ )

b. *Serzã-la pa ule fer èn dokter vini

(41) a. Mo fin tan dir sa nuvel-la

I PERF hear say that news-the

'I've heard that news being spread around'

b. *Mo fin tan sa nuvel-la dir 

a. Mo bizẽ fer dres mo kostim
I must make iron my suit
'I must have my suit ironed'
b. *Mo bizẽ fer mo kostim drese

In (38a), (39a), and (40b) the lower subject stays left of its $V$, but in (40a), (41a), and (42a) the lower V is immediately adjacent to the higher V. The principle to be extracted from this is that PR, for those verbs that are marked for this rule, is strongly conditioned, and that subject raising (SR) is the default option when PR is not or cannot be applied. An absolute condition on PR is that the lower $S$, after its cyclic treatment, has no more than one nominal argument (datives, with or without the dative preposition ar/ek/avek, count as nominal arguments). Thus a sentence like

Mo fin tan dir sa nuvel-la ar so papa

I PERF hear say that news-the by his father

'I have heard that news being spread around by his father'

can only be interpreted as meaning that it was the father who spread the news, that is, with a passive dir 'say', not that the news was broken to the father, despite the ambiguity of the preposition $a r$, which, like $e k$ and the direct French loan avek, is ambiguous between the dative preposition 'to' and the agent-phrase preposition 'by'.

Furthermore, when the first condition is fulfilled PR is obligatory when the lower $\mathrm{S}$ lacks a subject, either because it is passive or because the subject has been deleted by SD. Finally, when the lower grammatical subject is also the semantic subject and, of course, the lower S has only one NP argument, PR is optional, as appears from (40). When PR cannot or does not apply, SR applies. Given these conditions, we can conclude that at least the verbs vini, ale, kone, seye, rode, komãse, and lese (see [29] above), as well as fer, induce PR. As has been said, they are all well-known PR customers in all kinds of languages.

There can be little doubt that MC owes its rule of predicate raising in principle to French. Yet, the differences with regard to French are considerable and do not seem to be derivable from French. On the one hand, the class of MC PR-inducing verbs is notably larger than the corresponding French class (which consists mainly of faire, laisser, voir, entendre, and envoyer). On the other hand, PR is much more heavily conditioned in $\mathrm{MC}$ than it is in French. The question thus arises of the origin of these MC innovations. Are they "spontaneous" in the sense that they represent a selection from the options available for human languages without any substrate influence, or is there an African substrate? This question is relevant in the wider context of current debates around the conditions of Creole genesis. 
If an African language can be pointed out that is both a historically plausible source and sufficiently like $\mathrm{MC}$ as regards both the class of PR verbs and the conditions under which the rule applies, then substrate influence can hardly be denied. Yet even with substrate influence recognized, there still is the question of what determines or partly determines the selection made from different possible substrate (or superstrate) sources. However, for the case at hand, no African source has been found, and as long as this is so one is entitled to make provisional inferences regarding the inbuilt forces of language and their effects in creolization processes.

The way PR has been remodeled in $\mathrm{MC}$, as we shall see presently, strongly suggests that creolization processes are characterized by a tendency to maximize semantic transparency, or, in other words, to minimize the amount of processing required to get from semantic structures to linguistic surface structures and vice versa (see Seuren and Wekker 1986 for a detailed discussion of the role of semantic transparency in the genesis of Creole languages). This inference, however, must be heavily hedged because, first, very little is known about linguistic universals generally, so that we can only have a partial idea of the universal fund from which selections can be made when a Creole comes about. Then, second, the notion of semantic transparency is strictly theory-dependent in that it can be made explicit only in the context of a satisfactory and psychologically plausible theory of semantic structure and semantic processing. Such a theory is not available or not generally recognized as being available. Given these limitations, we shall have to strive for analyses that are minimally theory-dependent. ${ }^{22}$

From the point of view of semantic transparency $P R$ is an interesting rule because in some ways it enhances transparency while in other ways it is counterproductive in this respect. As is easily seen, the effect of cyclically stacked PR consists in (a) a clustering of verbs at one end of the sentence or clause, and (b) a clustering of NP arguments at the other end, while (c) the lower Ss disappear. The reader will quickly see the effects of the rule when PR, as formulated in (35), is applied on successive cycles. The removal of the lower S-node appears to be functionally advantageous. Virtually all semantic theories imply semantic structures (either as input to the rules of syntax or as "translations" into a logical language) with multiple propositional embeddings, that is, "vertical" structures, whereas linguistic surface structures show relatively little propositional embedding and are much more "horizontal." The rationale behind this is probably the tendency of proposition-forming operators to sit on the verb in the argument-S, as the verb is most directly affected: negation and tenses, for example, tend to sit on the verb. This implies a reduction of S-embeddings. 
On the other hand, repeated PR-application leads to clustering of verbs on one side and of NPs on the other side of the clause. This is semantically dysfunctional, as the semantic relations between the various NPs and verbs are now hard to establish, especially when crossing dependencies arise (as they do, for example, in Dutch). Such structures require a great deal of semantic reconstructing and are costly in terms of semantic processing.

In the light of these considerations it looks as if MC has struck an optimal balance between the advantages and the disadvantages of the $P R$ rule. It maximizes application of PR but only in those cases where the rule has no adverse effect on semantic transparency. There is thus a rationale behind the seemingly odd collection of conditions on this rule in MC. First note that semantic processing in MC is helped if the order subject-verb-object (SVO) is preserved, for the simple reason that the vast majority of sentences in MC have this order, while only a few, like some question forms (as in [16a] and [16b]), have VS, but never VSO. SR has the effect of maintaining SVO order, whereas PR (with right adoption) results in VSO for the embedded clause if that clause has both a subject and an object term. We now note that the conditions on PR as stated above ensure that VSO never occurs in surface structure: when the lower $\mathrm{V}$ has more than one argument, PR does not apply and SR takes over, thus preserving the SVO order. But if the lower V has only one argument, then, as we have seen, $\mathrm{PR}$ is obligatory for the verbs in question when the original subject is absent and the one argument in question is an original object term. The surface result is then that the object follows its verb, which is all right. Only when the one argument of the intransitive $S$ is the original subject of the lower $V$ will this subject follow its verb, as in (40a), so that PR leads to a VS order, but never to VSO, just like the question forms exemplified in (16a) and (16b) above. In such cases, as has been said, PR is optional. The conditions for application of PR in MC thus seem to ensure pretty well that standard SVO constituent order is maintained, with the small exception of a possible VS order, which also occurs in surface structures, though less frequently.

\section{Specific question words}

A feature that $\mathrm{MC}$ has in common with some Caribbean Creole languages (Alleyne 1980: 13) is the formation of specific question words (WH-words). Most specific question words in these languages are composed of a general WH-question marker, followed by a category marker for person, thing, manner, time, place, or kind. The category marker is 
usually an original noun, occasionally a verb. Sranan is a typical case in point. It has the following WH-words that follow this pattern:

$\begin{array}{llll}\text { who somebody } & >\text { o suma }>\text { suma 'who?' } \\ \text { who something } & >\text { o sani }>\text { san 'what?' } \\ \text { who place } & >\text { o pe }>\text { pe 'where?' } \\ \text { who time } & >\text { o ten }>\text { oten 'when?' } \\ \text { who fashion } & >\text { o fa }>\text { fa 'how?' } \\ \text { who sort } & >\text { o sortu }>\text { sortu 'which?, what kind?' }\end{array}$

This is found to a somewhat lesser extent in MC:

$\begin{array}{llll}\text { qui côté } & >\text { ki kote/kot } & \text { 'where?' } \\ \text { qui l'heure } & >\text { ki ler } & \text { 'when?' } \\ \text { qui manière } & >\text { ki manyer } & \text { 'how?' } \\ \text { qui faire } & >\text { ki fer } & \text { 'why?' }\end{array}$

Sometimes the original French WH-word was preserved:

$\begin{array}{llll}\text { quand } & >\text { kã } & \text { 'when?' } \\ \text { comment } & >\text { kuma } & \text { 'how?' } \\ \text { qui } & >\text { ki } & \text { 'what?' }\end{array}$

and in one case an idiosyncratic construction took over:

qui ça un-la $>$ kisanla 'who?'

This pattern of WH-word formation is neither unknown nor systematically applied in the European languages or indeed the languages of the world. In French, for example, one finds, next to comment, also de quelle manière for 'how?', or next to où also de quel côté for 'where?'. And English has what way along with how, etc. The same is found in a large number of African languages, especially in the West African group of Kwa languages, spoken in the eastern half of West Africa, where this process of WH-word formation is prominent. The analytic forms, consisting of a question marker with a category marker, are sometimes fully grammaticalized and may even undergo semantic shift. Thus, the Swahili expression for 'how?' is namna gani, literally 'sort which'.

The question is now whether MC has developed its analytic WH-words under influence of West African (i.e. Kwa) languages, or has done so independently due to a tendency toward semantic transparency. In the case of the Caribbean Creoles one is fully entitled to think of substrate influence, no doubt reinforced by factors of semantic transparency, in the formation of WH-words, since it is generally known that there is an enormous amount of Kwa substrate in these languages. However, as regards $\mathrm{MC}$, the situation is different. To answer the question for $\mathrm{MC}$ 
much will depend on the historical possibility of Kwa influence in MC during the period considered crucial by Baker and others. The available information points to Senegal and to Benin (Ouidah) as the main geographical origins of the West African slaves imported between 1728 and 1740. No Kwa language is, obviously, spoken in Senegal, but some of the languages spoken in Benin nowadays are Kwa languages. This being so, the case for West African influence as regards MC WH-words is not untenable, though by no means strong. As so often, it is now practically impossible to trace the precise developments as they took place a few hundred years ago. What we may safely assume, however, is that factors of semantic transparency have reinforced whatever substrate influences were present. Clearly, substrate influences stand a much better chance of survival in a Creole language when they enhance semantic transparency and thus make the acquisition and the use of the language easier. We therefore assume that the analytic and semantically transparent WH-forms, widely available in lexifier and source languages, were in a better position of survival than the synthetic European WH-words.

\section{Tense modality and aspect: the MC TMA system}

One of the outstanding features of Creole languages is their way of expressing tenses, modalities, and aspects by means of preverbal particles, arranged in that order. Hence one speaks of the Creole TMA system. It is found in the vast majority of what are recognized as Creole languages, though with considerable differences. The origins of the Creole TMA system are a matter of dispute. Some (e.g. Alleyne 1980: 162-165) prefer a West African substrate source. They point out that a preverbal particle system also occurs in the Kwa languages. However, prima facie the similarities are not too striking, and postverbal marking is also found in these languages. On the other hand, tense and aspect systems in the European lexifier languages are complex and hard for foreign learners to master. It is to be expected that makeshift means are developed to circumvent these difficulties, and the obvious strategy is to use adverbials and verbs (as happened when Latin developed into the Romance languages). Inbuilt linguistic forces were therefore certainly called upon to find the right strategy with the highest semantic transparency. A single Kwa substrate origin for all the Creole TMA systems in the whole wide world is not very likely anyway. Moreover, why should factors of semantic transparency not have been at work also in the Kwa languages? It seems wise, therefore, to take the point of view that, whatever substrate influence may have reinforced the emergence of Creole TMA systems, 
the main driving force behind them must have been the wish to maximize semantic transparency.

The striking fact is that, in its general form, the Creole TMA system is highly transparent from a semantic point of view, and the specific MC version of the TMA system is even almost completely semantically regular and thus exceptionally transparent.

MC has an overt tense marker $t i$, expressing the deictic PAST. A second past marker is deza (French déjà), expressing perfect or pluperfect (see below). That is, like the English simple past tense, $t i$ refers back to a given period or moment in the past with respect to the time of speaking. It is discourse-dependent in that the time referred to must be specified in preceding discourse or in the situation (just like the reference function of definite NPs). Deza corresponds roughly to the English perfect tense auxiliary have, including its use in the pluperfect (but see also [51] below, where the pluperfect is formed with $t i-f i n)$ :

(44) $\mathrm{Nu}$ ti deza deside pu partaz sa larises-la ek lepep we PAST PREC decide to share that wealth-the with people 'We had decided to share that wealth with the people' (Virahsawmy ZM)

Besides the past tense marker, $\mathrm{MC}$ has two aspect markers, pe for the expression of progressive continuative or habitual aspect, and fin for the perfective resultative aspect. Fin can be intensified by reduplication: finfini, expressing final result (cf. [21b] and [21c] above):
$\mathrm{Pa}$ fin-fini
regle sa
not PERF-INTENS settle that
'That has not been finally settled'
(Virahsawmy ZM)

The continuative marker pe derives from French après in its original sense of 'close by, at', still extant in many dialects. Fin, of course, has the French fini as its source, with verb apocope as it will always be VP-internal. If we call subjectless verbal forms in a lower VP infinitival and the main verb of a clause finite, we see that $t i$ occurs only with finite forms but pe also with infinitivals:
a. Tan laful pe kriye ${ }^{23}$
hear crowd CONT cry
'One hears how the crowd are shouting'
(Virahsawmy ZM)
b. Li paret pe tufe
he seem CONT choke
'He seems to be choking'
(Virahsawmy ZM) 
However, pe does not occur with verb forms embedded in a cluster created by PR. Thus (cf. [29c] above), the following is ungrammatical:

c. *Mo fin tan pe dir sa

This is in accordance with what is observed in PR constructions generally: verbs incorporated into a PR cluster are always bare verbs, without negative or aspectual or other operators added.

Fin, though often translated as a perfect (Mo fin aste 'I have bought') is as aspectual as it is temporal. It also occurs with adjectivals, expressing the state of having become so and so:
a. Li fin malad he PERF sick
'He has fallen ill'
b. Li fin kapav fer so devwar
he PERF able do his duty
'He is now capable of doing his duty'

Its general meaning is something like 'it has come the point where ...', as in
a. Li fin midi
it PERF noon
'It has become midday'
(Virahsawmy $L i$ )
b. Li fin degut so lavi
he PERF disgust his life
'He has come to despise his life'
(Virahsawmy ZM)

Like pe, fin is also allowed to occur with infinitivals (except in PR-clusters):

(49) To bizẽ fin mãze ler mo vini you need PERF eat when I come

'You must have finished eating when I arrive'

It pays in many ways to interpret fin and pe as deep-structure verbs, that is, at the level of semantic representation. Historically, this is correct for fin but not for pe. MC has two verbs fini, both from French finir. One is the TMA auxiliary that appears as the truncated fin, the other is the regular [+VA] main verb fini 'finish'. Thus, the following sentence is ambiguous: 


\section{(50)}

Li fin fini mãze
he PERF-INTENS eat
'He has definitely eaten'

Li fin fini mãze he PERF finish eat 'He has finished his meal'

If $p e$ and fin are considered deep-structure verbs they can be said to take their propositions as their sentential subjects, in much the same way as other aspectual verbs like English stop, begin, continue or the epistemic modals must, may, will, etc.

Since Reichenbach (1947) most authors on tense analysis have assumed a semantic system of two tenses, the "double tense analysis." The highest tense, $t_{1}$, refers to a contextually defined moment, either the present or a past moment or period, that is, PRES or PAST. PRES is lexicalized as $\emptyset$, PAST as $t i$. The second tense, $t_{2}$, is more aspectual, though with tense elements, in particular in the value deza. It takes as possible MC values $\emptyset$ ('simultaneous'), PERF ('action finished'), CONT ('action lasting'), or PREC ('previous to $t_{1}$ '). PERF is lexicalized as fin, CONT as pe, PREC as deza. As we saw in (44), deza can form the pluperfect, but it is not as common as the pluperfect in the European languages. Another way of expressing the pluperfect is the combination $t i-f i n$ :

(51) Mo ti fin van loto-la

I PAST PERF sell car-the

'I had sold the car'

This analysis, with the tenses (aspects) as V-nodes, gives rise to the following configuration: ${ }^{24}$

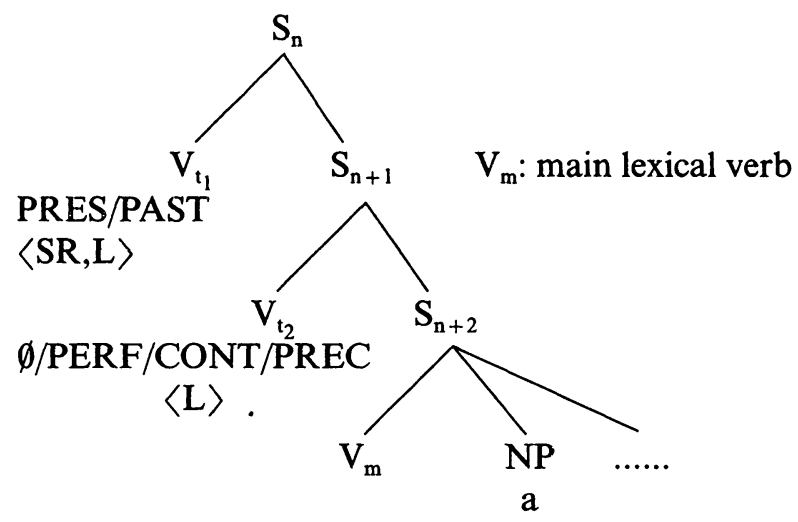

For both $t_{1}$ and $t_{2}$ the lowering operation ( $L$ ) involves left-adoption of the higher V by the lower V. SR is standard subject raising. The tense routine is thus as follows: 


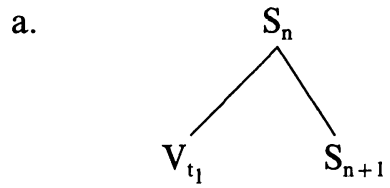

PRES/PAST $\langle\mathrm{SR}, \mathrm{L}\rangle$ $\emptyset / \mathrm{PERF} / \mathrm{CONT} / \mathrm{PREC}$ $\langle\mathrm{L}\rangle$
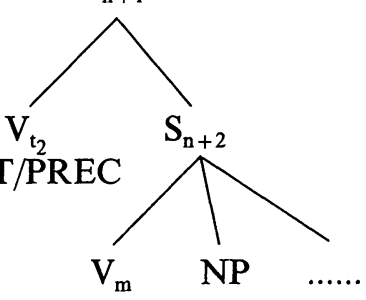

a
$\mathrm{L} \Rightarrow \mathrm{b}$.

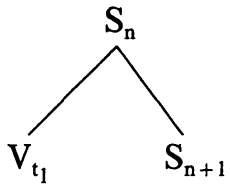

PRES/PAST $\langle\mathrm{SR}, \mathrm{L}\rangle$ $\emptyset / \mathrm{PERF} / \mathrm{CONT} / \quad \mathrm{V}_{\mathrm{m}}$ PREC
$\mathrm{SR} \Rightarrow \mathrm{c}$.

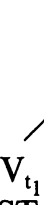

PRES/PAST

$\langle\mathrm{L}\rangle$

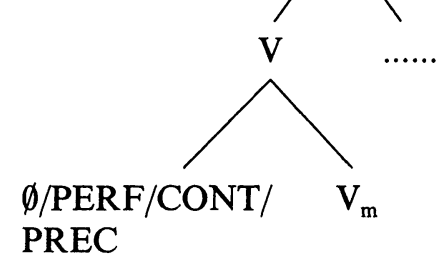

$\mathrm{L} \Rightarrow \mathrm{d}$.

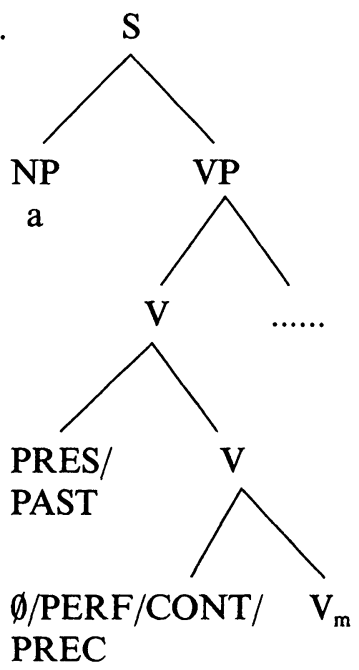

The derivation provided above for (29a) in (36) proceeds precisely along the lines of (53). The (re)labelling of the tense/aspect predicates after lowering differs from language to language. In the European languages PRES and PAST are usually relabelled as Affix. The $t_{2}$ predicate stays V in languages with a perfect auxiliary verb (e.g. English have) but is also relabelled as Affix in languages with a morphological perfect and pluperfect, like Latin. In MC it is probably advisable to relabel all tense and/or aspect predicates as Particle, but this has not been made part of the general configuration in (52) or in the derivational diagrams provided. 
The MC modals $p u$ 'future' and ( $v) a$ 'immediate future' have their own special place in the tense system. They cannot occur as infinitives, just like the English modals can, may, must, will, etc. Nor do they have a perfect or pluperfect tense, again as in English. They can only occur in the present or simple past tense. The obvious solution is to assign them a place between $t_{1}$ and $t_{2}$, precisely as has to be done for the English modals. ${ }^{25}$ With modals, the general configuration (52) now becomes (54a). The cyclic treatment of all the elements concerned leads to the schematic end-cyclic ("shallow") structure (54b). One notes the uncanny similarity with the English system, which likewise has the modals placed between $t_{1}$ and $t_{2}$, which automatically explains their defective paradigm. In a way, therefore, English may be said to have an underlying TMA system. The difference with the Creole languages is that, in the latter, the TMA system is visible at the surface level in the ordering of the TMA particles.

a.

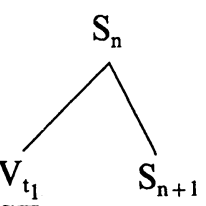

PRES/PAST

$\langle\mathrm{SR}, \mathrm{L}\rangle$

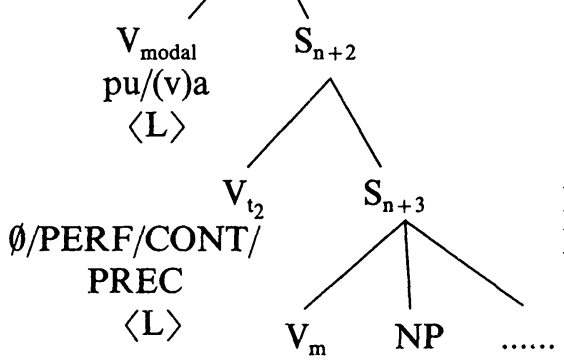

a

$\Rightarrow \mathrm{b}$.

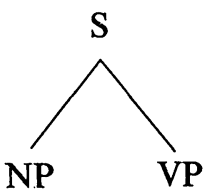

\section{T}

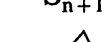

a

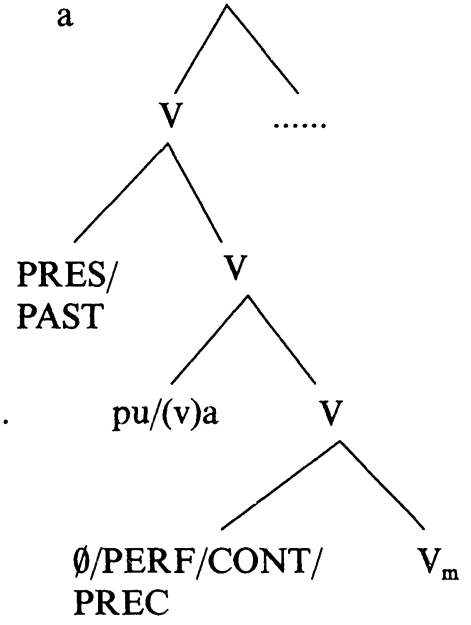

The MC TMA system can thus be presented taxonomically as follows:

\begin{tabular}{|c|c|c|}
\hline \multicolumn{1}{c}{$T$} & $\mathrm{M}$ & $\mathrm{A}$ \\
\hline ti & $\begin{array}{c}\text { pu } \\
\text { (v)a }\end{array}$ & $\begin{array}{c}\emptyset \\
\text { fin } \\
\text { pe } \\
\text { deza }\end{array}$ \\
\hline
\end{tabular}


This allows, for example, for the sentence

(56) Avinas ti pu mãz kari-la

Avinas PAST FUT eat curry-the

'Avinas would eat the curry'

which is derived in the following way:

(57)

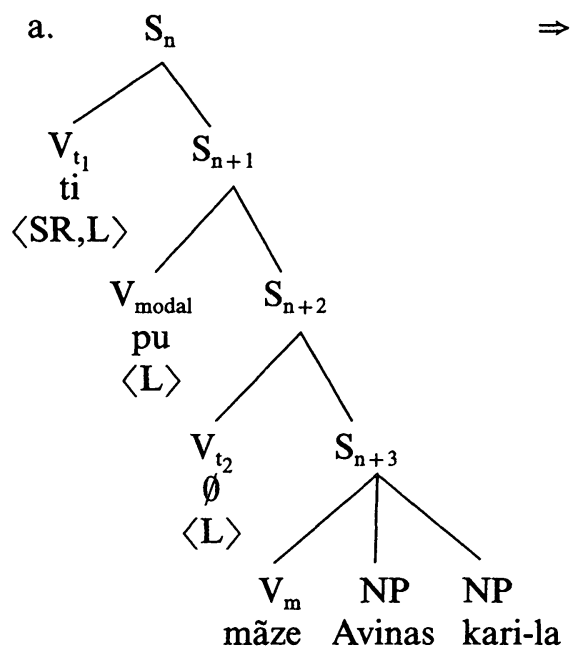

$\Rightarrow \quad$ c. $\quad \mathrm{S}_{\mathrm{n}}$

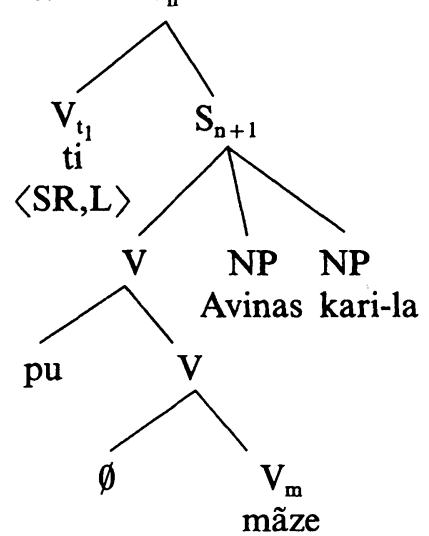

$\Rightarrow$ b.

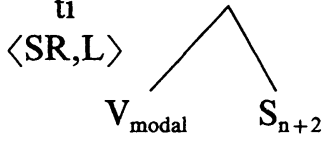

$\mathrm{pu}$

$\langle\mathrm{L}\rangle$

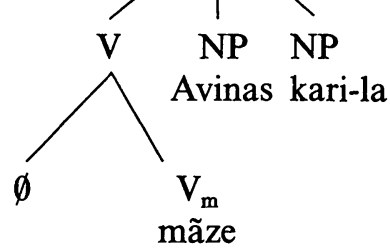

$\Rightarrow \mathrm{d}$.

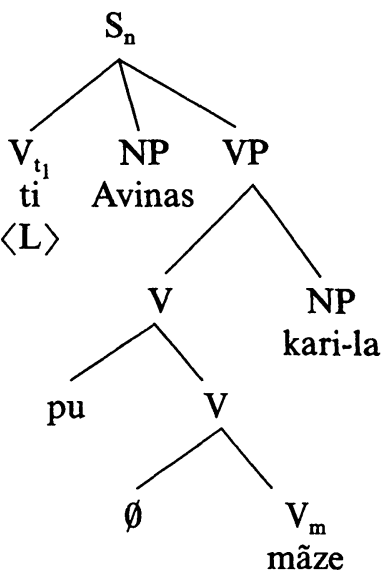




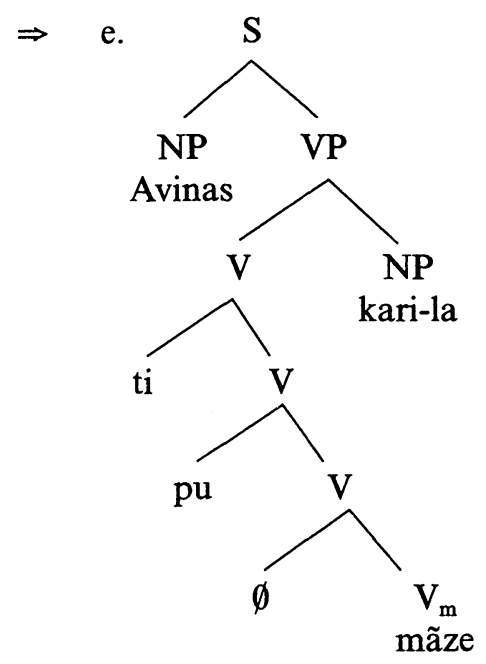

But it disallows, for example,
a. *Li pe va fer sa he CONT FUT do that ' $\mathrm{He}$ is going to do that'
b. *Li pe ti mãz kari-la (cf. [56])
c. *Mo fin ti van loto-la (cf. [51])

The system also disallows sentences with $p u$ or $(v) a$ in infinitivals, as in (59)

*To kapav pu tuy li you able FUT kill him

'It is possible that you will kill him'

because S-embeddings (clause complementation) may be (a) tenseless (i.e. $\mathrm{S}_{\mathrm{n}+3}$-embedding), or single-tensed (i.e. $\mathrm{S}_{\mathrm{n}+2}$-embedding), or doubletensed (i.e. $S_{n}$-embedding), but $S_{n+1}$-embedding, that is, a modal plus the rest, is not allowed (see Seuren i.p.: section 2.12 for a full discussion with respect to English and other European languages). This corresponds, of course, with the fact that the English modals lack infinitival forms.

Finally, sentences like the following are excluded:

$$
\begin{aligned}
& \text { *Li pe kõtã sa fam-la } \\
& \text { he CONT love that woman-the } \\
& \text { 'He is loving that woman' }
\end{aligned}
$$

on account of the restriction on pe that makes it combine only with nonstative main lexical verbs in the S-structure just below it. 
The main point to be demonstrated is that the surface structure of MC is an almost complete and in any case faithful reflection of the underlying semantic analysis. The order in which the TMA particles occur reflects their scope in the semantic trees. No cyclic or postcyclic rules disturb this regular picture. The only rules needed to get through the tense routine are lowering and subject raising, neither of which disturbs the semantic transparency of the TMA elements in surface structure.

\section{Conclusion}

Our analysis confirms the claim that Creole languages are a linguistically characterizable set, though with vague boundaries, inasmuch as they show certain strategies that set them off against languages with a longer history and greater sociolinguistic spread, and, above all, suffering less from the heavy constraints on use and acquisition that are typical of Creole languages during their formative period. It is precisely the miserable circumstances of the people speaking and developing Creole languages that explain why whatever can be detected as typical Creole language features is likely to be due to a need for maximal semantic transparency. For the Creoles had to be easy to learn not only for adult newcomers in the slave community but also for small children, whose mothers had no time to spare for the kind of patient language teaching found in more privileged communities. If Creole languages are indeed semantically more transparent this would mean that a more limited use is made of the innate possibilities of grammar, so that they provide a relatively impoverished picture of whatever the innate language system amounts to.

Received 12 December 1994

University of Nijmegen

Revised version received

6 February 1995

\section{Notes}

1. Most of the research for this study was carried out during a six weeks' stay in Mauritius. I must acknowledge my debt to Dev Virahsawmy for letting me profit from his great knowledge of MC and of Mauritian affairs generally, and to all those kind Mauritians who did not tire of answering my questions about their language. I am also indebted to two anonymous referees, whose comments have helped to improve the paper on various counts. Correspondence address: Institute for General Linguistics 
and Dialectology, University of Nijmegen, P.O. Box 9103, 6500 HD Nijmegen, The Netherlands.

2. See Stein (1984) for a detailed survey of the sociolinguistic situation in Mauritius.

3. Chaudenson (1979c: 59-60) denies intercomprehensibility for French-based Creoles in general. My experience with MC speakers unpreparedly exposed to Haitian conversation strongly contradicts Chaudenson's position.

4. Annegret Bollée informs me that, interestingly, the same feature is also found in Canadian French.

5. This fits in well with the $25 \%$ given by Baker for the year 1740 (Baker and Corne 1982: 205). Remarkably, Bernardin de St. Pierre (1983 [1773]: 116) even implies that the "Nègres" in Mauritius during his visit (1768-1770) were not West Africans: "Des Nègres: Cette nation n'a ni le nez si écrasé ni la teinte si noire que celle des Nègres de Guinée. Il y en a même qui ne sont que bruns."

6. The Creole of Réunion differs more from MC than one might perhaps expect on the grounds of their geographic proximity. In general, as observed by various authors (Chaudenson 1979c; Bollée 1977: 111), Réunionnais has stayed closer to French than the other French-based Creoles. For Bollee this is an argument that, for the Indian Ocean French Creoles, there was no prior pidgin preceding the Creole. This argument is stronger for Réunionnais than for MC (see also Stein 1984: 92). Bollée's extrapolation from the former to the latter is based on the view, taken over from Chaudenson, that "there is a clear genetic dependence" between MC and Réunionnais (Bollée 1977: 115). Subsequent literature (in particular Baker and Corne 1982) has, however, conclusively shown the opposite.

7. Sentence (1a) is from Herskovits and Herskovits (1936: 188); (1b) was observed by the author; (1c) is from Trefossa, in Voorhoeve and Lichtveld (1975: 210); (1d) was provided by Mark Sebba.

8. See Gruber (1967).

9. A fact called "frightfully embarrassing" by Welmers (1973: 371). See, however, the excellent survey of serial verb constructions in Alleyne (1980: 167-171). None of the examples given is translatable into MC with maintenance of grammatical structure. For an attempt at a general definition see Seuren (1990a, 1991).

10. See Seuren (1985: 172-188) and Seuren (i.p.) for detailed and complete analyses of the predicate raising constructions in Dutch, German, and French.

11. Bickerton (1989) tried again to establish the case for verb serialization in the Frenchbased Indian Ocean Creoles, in particular Seychellois (Seselwa). The reply in Seuren (1990b) would seem to be decisive.

12. See Seuren (1993) for further discussion of predicate clefting in the Indian Ocean Creoles.

13. Se is also used as a comment indicator:

(i) So heritye se mwa

hisheir be me

'His heir, that's me'

(Virahsawmy ZM)

(ii) Li se nu veritab alye

he be our real ally

'Our real ally, that's him'

(Virahsawmy ZM)

14. I consider Corne's term final vowel truncation less appropriate as it is not always the vowel that is truncated. The traditional term apocope, though somewhat abstruse, 
covers the phenomenon precisely. (My original term syncopation is incorrect, as was pointed out by a referee.)

15. Corne's discussion (Baker and Corne 1982: 49-54, 67-72) is the most notable attempt in the literature at formulating the conditions under which VA takes place. Corne makes the rule contingent upon a notional category "Action" ("Rule $\langle V A\rangle$ signals Action" [Baker and Corne 1982: 54]), which, however, remains undefined. In general, the view that grammatical phenomena can be conditioned by extralinguistic, often cognitive, factors is widespread and, to my mind, essentially correct. But in the cases where this applies it does not make a description of the structural properties of the phenomena in question superfluous, even if the cognitive factors involved cannot be precisely defined. In this case it seems that, as Baissac intuited, the structural difference is whether or not the verb in question is VP-final: when it is not VA applies, and when it is VA does not apply. However, whether or not a particular constituent is part of VP is largely dependent on cognitive factors: sentential adjuncts tend to be outside VP whereas "lower" adjuncts, which are more closely related to the lexical main verb, tend to be inside VP. In this respect VA does indeed seem to reflect cognitive decisions made by the speaker, though these are hardly to do with a notional category of "Action." In general, it must be said that Corne's treatment of the phenomena in question lacks the necessary rigor and precision.

16. Compare the different positions of early in He got up early in London versus He got to London early. In the former, early is more like a manner adverb, but in the latter it is an adverb of time. For extensive comment, see Seuren (i.p: section 3.5).

17. (20a) was uttered in ordinary conversation and was meant as a general statement about climatic conditions somewhere in the world, in the context of a TV programme. The 'you' was meant generically as 'one'. When I pointed out to the speaker, who is careful and conscious in her use of MC, that she had produced that sentence and asked her if (20b) would also be good MC, she answered immediately that both were correct, but with a difference in meaning. She found it hard to make the difference explicit but settled on the statement that (20a) applies more generally and (20b) only to the individual sensation of being cold. If my interpretation of this difference is correct we may stipulate that VA does not apply to "free" readings when there is an opposition with a collocation reading.

18. In reduplicated verbs the first half is truncated by VA. Baker (1972: 102) distinguishes a second form of reduplication, where both forms are nontruncated: $N$ it marse-marse 'We walked and walked'. It seems, however, that this is more like asyndetic conjunction than a morphological phenomenon. The standard reduplication indicates intensification or hesitative repetition.

19. See Labov (1969) for copula deletion in New York Black English, Seuren (1981) for the same in Sranan. Corne (Baker and Corne 1982: 34-35) rejects any idea of an underlying copula and deletion by a (late) deletion rule (like VA). His reasons, however, hardly seem relevant. He argues (a) that the deletion analysis "supposes that the literally overwhelming majority of 'copulative' sentences ... which do NOT contain any surface copula (type mo malad 'I am ill') are in some way less basic than the minority of sentences which do contain ete." This, however, is a misconception of the notion of deletion in transformational grammar: deletion and being "less basic" in whatever sense are totally unrelated notions. Then (b), that "the recoverability criterion for deletion rules is not met, in that there are no cases where *mo ete malad 'I am ill' is a conceivable ... sentence." Here again, Corne proves uninformed on TG. The recoverability criterion was first proposed in Katz and Postal (1964: 79-80). It requires that any deletion be uniquely recoverable on the basis of rule properties or of lexical 
properties (features). It certainly does not require that the nondeleted form should somehow also be grammatical.

20. Ete should not be confused with the verb ena, which means either 'there is/are' or 'have'. Ena is never truncated.

21. Adoption is a standard syntactic routine. ' $\mathrm{X}$ adopts $\mathrm{Y}$ ' means that a copy of $\mathrm{X}$ is placed above $\mathrm{X}, \mathrm{Y}$ is detached from its position and attached to the new copy, either to the right (right adoption) or to the left (left adoption).

22. The notion that Creole languages are typically characterized by their semantic transparency is not new. Goodman (1964: 104) quotes a seventeenth-century French author saying, "the Negroes are articulate and intelligent; being attentive observers they become quickly familiar with the language of the European, a language voluntarily corrupted so as to facilitate its comprehension." Baissac (1880: ii-iii) writes, "The Creole, on the contrary, was born, almost overnight, from the overarching necessity, imposed on the masters as much as on the slaves, to create for themselves, as quickly as possible and at any cost, a tool for interaction, no matter what. The slave had to learn the language of the master and to speak it immediately." And many more authors could be quoted representing the general and nonspecific view that Creole languages should be uncomplicated and easy to learn, due to practical needs. Until Seuren and Wekker (1986), however, no author pursued this idea systematically to locate the structural features of Creole languages actually exhibiting the maximization of semantic transparency.

23. MC has a zero subject for the generic one, French on.

24. See Seuren (1981) for a similar analysis of the Sranan TMA system.

25. See Seuren (i.p.: sections 2.11, 2.12, 3.4, 3.8) for extensive discussions of the English modals.

\section{References}

Alleyne, Mervyn C. (1980). Comparative Afro-American. An Historical-Comparative Study of English-Based Afro-American Dialects of the New World. Ann Arbor: Karoma.

Baissac, Charles (1880). Etude sur le patois créole mauricien. Nancy: Berger-Levrault. -(1888). Le folk-lore de l'île Maurice. Paris: Maisonneuve and Larose.

Baker, Philip (1972). Kreol. A Description of Mauritian Creole. London: Hurst.

-; and Chris Corne (1982). Isle de France Creole: Affinities and Origins. Ann Arbor: Karoma.

Bernardin de Saint-Pierre, Jacques-Henri (1983 [1773]). Voyage à l'île de France, Un officier du roi à l'île Maurice. 1768-1770. Paris: La Découverte/Maspero.

Bickerton, Derek (1981). Roots of Language. Ann Arbor: Karoma.

-(1984). The language bioprogram hypothesis. Behavioral and Brain Sciences 7(2), 173-221.

-(1989). Seselwa serialization and its significance. Journal of Pidgin and Creole Languages $4(2), 155-183$.

Bollée, Annegret (1977). Zur Entstehung der Kreolendialekte im Indischen Ozean. Kreolisierung ohne Pidginisierung. Geneva: Droz.

Chafe, Wallace (1970). Meaning and the Structure of Language. Chicago: University of Chicago Press.

Chaudenson, Robert (1979a). À propos de la genèse du créole mauricien: le peuplement de l'île de France de 1721 à 1735. Études Créoles 2, 43-57. 
- (1979b). Créoles français de l'Océan Indien et langues africaines. In Readings in Creole Studies, I. Hancock et al. (eds.), 217-237. Ghent: Storia-Scientia.

-(1979c). Les créoles français. Collection Langues en Question. Éditions Fernand Nathan.

-(1981). Textes créoles anciens (La Réunion et Île Maurice): comparaison et essai d'analyse. Hamburg: Buske.

-(1984). Où l'on parle de la genèse et des structures des Créoles de l'Océan Indien. Études Créoles 6(2), 157-237.

Chomsky, Noam (1981). Lectures on Government and Binding. The Pisa Lectures. Dordrecht: Foris.

Corne, Chris (1970). Essai de grammaire du créole mauricien. Auckland: Linguistic Society of New Zealand.

Faine, Jules (1939). Le créole dans l'univers. Études comparatives des parlers français créoles, vol. 1: Le mauricien. Port-au-Prince: Imprimerie de l'État.

Filliot, Jean M. (1974). La traite des esclaves vers les Mascareignes au XVIIIe siècle. Mémoires ORSTOM 72. Paris: Office de la Recherche Scientifique et Technique OutreMer.

Goodman, Morris, F. (1964). A Comparative Study of Creole French Dialects. The Hague: Mouton.

Grevisse, Maurice (1969). Le bon usage. Grammaire française avec des remarques sur la langue française d'aujourd'hui. Paris: Duculot-Geuthner.

Gruber, Jeffrey (1967). Functions of the Lexicon in Formal Descriptive Grammars. TM-3770/000/0. Santa Monica, CA: System Development Corporation.

Hancock, Ian; Polome, Edgar; Goodman, Morris; and Heine, Bernd (eds.) (1979). Readings in Creole Studies. Ghent: Storia-Scientia.

Herskovits, Melville J.; and Herkovits, Frances S. (1936). Suriname Folklore. New York: Columbia University Press.

Hollingworth, P. D. (1961). The Place-Names of Mauritius. Port Louis: Government Printer. Hull, Alexander (1979). On the origin and chronology of the French-based Creoles. In Readings in Creole Studies, I. Hancock et al. (eds.), 201-215. Ghent: Storia-Scientia.

Katz, Jerrold J.; and Postal, Paul M. (1964). An Integrated Theory of Linguistic Descriptions. Cambridge, MA: MIT Press.

Kuno, Susumo (1973). Functional Syntax. Chicago: University of Chicago Press.

Labov, William (1969). Contraction, deletion, and inherent variability of the English copula. Language 45(4), 715-762.

McCawley, James D. (1970). English as a VSO language. Language 46(2), 286-299.

Muhlhäusler, Peter (1979). Growth and Structure of the Lexicon of New Guinea Pidgin.

Canberra: Australian National University, Department of Linguistics.

Napal, Dayachand (1980). Dutch Mauritius and Île de France. (1638-1810). Private edition. Reichenbach, Hans (1947). Elements of Symbolic Logic. New York: Macmillan.

Ruwet, Nicolas (1991). Syntax and Human Experience. Chicago and London: University of Chicago Press.

Seuren, Peter A. M. (1981). Tense and aspect in Sranan. Linguistics 19, 1043-1076.

-(1985). Discourse Semantics. Oxford: Blackwell.

-(1990a). Serial verb constructions. In When Verbs Collide: Papers from the 1990 Ohio State Mini-Conference on Serial Verbs, Brian D. Joseph and Arnold M. Zwicky (eds.), 14-33. Columbus: Ohio State University Department of Linguistics.

- (1990b). Still no serials in Seselwa. Journal of Pidgin and Creole Languages 5(2), 271-292.

-(1991). The definition of serial verbs. In Development and Structure of Creole Languages, F. Byrne and T. Huebner (eds.), 193-205. Amsterdam: Benjamins.

-(1993). The question of predicate clefting in the Indian Ocean Creoles. In Focus and 
Grammatical Relations in Creole Languages, F. Byrne and D. Winford (eds.), 53-64. Amsterdam: Benjamins.

-(i.p.). Semantic Syntax. Oxford: Blackwell.

-; and Wekker, Herman (1986). Semantic transparency as a factor in Creole genesis. In Substrata versus Universals in Creole Genesis. Papers from the Amsterdam Creole Workshop, April 1985, P. Muysken and N. Smith (eds.), 57-70. Amsterdam: Benjamins.

Stein, Peter (1984). Kreolisch und Französisch. Tübingen: Niemeyer.

Toussaint, Auguste (1974). Histoire de l'île Maurice. Paris: Presses Universitaires de France. Van Kuppevelt, Jan (1991). Topic en comment. Expliciete en impliciete vraagstelling in discourse. Unpublished Ph.D. thesis, Nijmegen University.

Virahsawmy, Dev (1967). Towards a re-evaluation of Mauritian Creole. Unpublished diploma dissertation in Applied Linguistics, Edinburgh University.

-(n.d.a.). $L i$ (stage play). Privately printed.

-(n.d.b.). Zeneral Makbef(ZM) (stage play). Privately printed.

Voorhoeve, Jan; and Lichtveld, Ursy (eds.) (1975). Creole Drum. An Anthology of Creole Literature in Surinam. New Haven and London: Yale University Press.

Welmers, William E. (1973). African Language Structures. Berkeley, Los Angeles, London: University of California Press. 